Atmos. Chem. Phys. Discuss., 9, 16131-16162, 2009 www.atmos-chem-phys-discuss.net/9/16131/2009/ (C) Author(s) 2009. This work is distributed under the Creative Commons Attribution 3.0 License.

This discussion paper is/has been under review for the journal Atmospheric Chemistry and Physics $(A C P)$. Please refer to the corresponding final paper in $A C P$ if available.

\title{
Attribution of ozone radiative forcing trend to individual $\mathrm{NO}_{\mathrm{x}}$ sources
}

\section{K. DahImann, V. Grewe, M. Ponater, and S. Matthes}

Deutsches Zentrum für Luft- und Raumfahrt, Institut für Physik der Atmosphäre, Oberpfaffenhofen, Germany

Received: 10 June 2009 - Accepted: 20 July 2009 - Published: 28 July 2009

Correspondence to: K. Dahlmann (katrin.dahlmann@dlr.de)

Published by Copernicus Publications on behalf of the European Geosciences Union.

Attribution of ozone radiative forcing trend to individual

$\mathrm{NO}_{x}$ sources

K. Dahlmann et al.

K. Dahlmann et al.

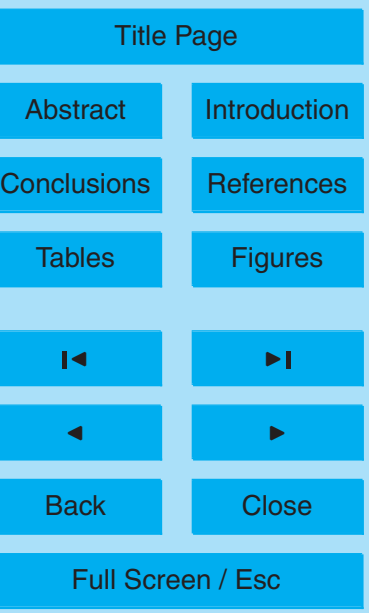

Printer-friendly Version

Interactive Discussion 


\section{Abstract}

Decadal means of ozone fields from transient E39/C climate-chemistry simulations (1960-2019) are analysed and temporally developing ozone radiative forcings (RF) are investigated which result from individual ozone precursor sources like road

5 traffic, industry, air traffic, etc. We study how effective $\mathrm{NO}_{\mathrm{x}}$ emissions from different sources produce ozone. This ozone production efficiency is mainly dependent on the altitude of $\mathrm{NO}_{\mathrm{x}}$ emission and on the amount of background $\mathrm{NO}_{\mathrm{x}}$. For example, our study shows that the ozone production efficiency of lightning and air traffic have a five and two time higher ozone production efficiency than ground based sources.

10 The radiative efficiency of ozone (i.e. the radiative forcing per molecule) is mainly dependent on the surface temperature, but also, to a lesser degree, on the altitude of added ozone. Lightning, for example, causes the highest specific RF due to the fact that lightning primarily enhances ozone in low latitudes in the mid-troposphere. Superimposed on these effects, is a saturation effect which causes a decreasing RF efficiency with increasing background ozone. A consequence of this saturation effect is an underestimation of total RF by about $10 \%$ if the component RFs of individual ozone sources are calculated separately and added up afterwards. The results show that the time development of emissions (1960-2019) control the RF changes for most sources. RF changes are slightly reduced due to a changing atmospheric composition (10-25\%) for all but the aircraft sources, and due to RF saturation (2-5\%).

\section{Introduction}

Ozone changes have a significant impact on climate (Ramanathan et al., 1976; Ramanathan and Dickinson, 1979; Fishman et al., 1979; Wang et al., 1980). Ozone is the third most important greenhouse gas perturbed by human activity, next to carbon dioxide $\left(\mathrm{CO}_{2}\right)$ and methane $\left(\mathrm{CH}_{4}\right)$. The ozone effect is a combination of infrared green-

\section{Attribution of ozone radiative forcing trend to individual $\mathrm{NO}_{x}$ sources}

K. Dahlmann et al.

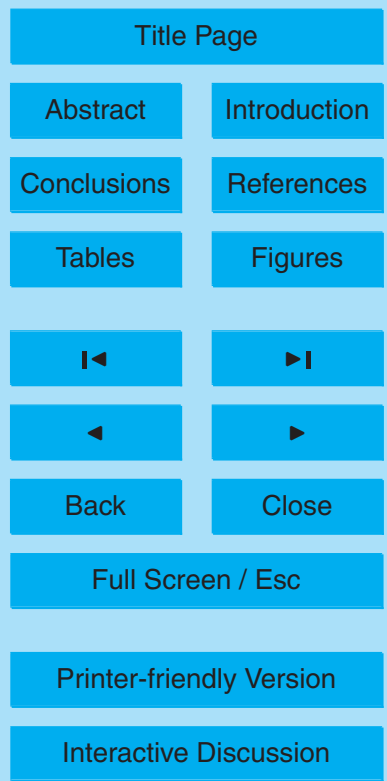

\section{2}


house warming and shortwave absorption, the latter contributing a negative radiative forcing at the tropopause for stratospheric ozone increase but a positive forcing for tropospheric ozone increase. Tropospheric ozone is produced primary through the reaction:

$5 \quad \mathrm{HO}_{2}+\mathrm{NO} \rightarrow \mathrm{NO}_{2}+\mathrm{OH}$

$\mathrm{NO}_{2}+h v \rightarrow \mathrm{NO}+\mathrm{O}\left({ }^{3} \mathrm{P}\right)$

$\mathrm{O}\left({ }^{3} \mathrm{P}\right)+\mathrm{O}_{2} \rightarrow \mathrm{O}_{3}$

An enhanced $\mathrm{NO}_{\mathrm{x}}\left(=\mathrm{NO}+\mathrm{NO}_{2}\right)$ emission leads to an enhanced tropospheric ozone production. The impact of $\mathrm{NO}_{\mathrm{x}}$ emissions on the ozone budget has been discussed 10 recently, e.g. for air traffic emissions (IPCC, 1999; Grewe et al., 2002; Köhler et al., 2008), ship emissions (Eyring et al., 2007) and emissions from road traffic (Granier and Brasseur, 2003; Matthes et al., 2007). Globally, there is an upward trend in ozone precursor $\left(\mathrm{NO}_{\mathrm{x}}\right)$ of different sources, leading to a strong increasing trend in tropospheric ozone abundance. Industry and air traffic for example have shown a rapid increase in $\mathrm{NO}_{\mathrm{x}}$ emissions since 1960 and an ongoing increase in the next decades and further ozone increase in the troposphere is expected. By contrast the ozone amount in the stratosphere has decreased from 1970 to 2000 due to emission of CFCs (e.g. WMO, 2003; Dameris et al., 2006).

In order to quantify how an ozone source perturbs the global climate we calculate the radiative forcing $(\mathrm{RF})$. The concept of $\mathrm{RF}$ has been extensively used indicating the potential importance of climate change mechanisms (e.g. IPCC, 1990, 1992, 1995, 1999, 2007). It allows a first order estimate of the global-mean surface temperature change without the need for time-consuming and computationally expensive 3-D simulations of the climate system on the assumption of an approximately linear relationship between

the global mean RF and the equilibrium response of global mean surface temperature $\Delta T_{\text {surf }}$ (e.g. Dickinson, 1982; Hansen et al., 1997; Stuber et al., 2001). The climate sensitivity parameter $\lambda$ relates the climate forcing to the climate response: $\Delta T_{\text {surf }}=\lambda \mathrm{RF}$. The RF concept enables to compare forcings from different mechanisms, even if these

\section{Attribution of ozone radiative forcing trend to individual $\mathrm{NO}_{x}$ sources}

K. Dahlmann et al.

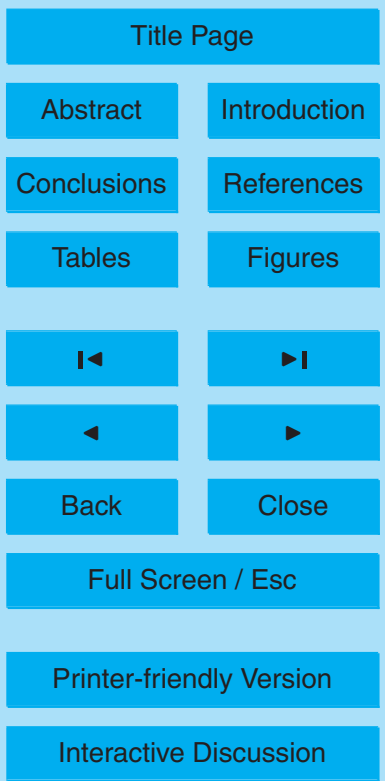


are too small as to give a statistically significant climate response in 3-D simulations.

Lacis et al. (1990) showed that the radiative forcing produced from a certain amount of ozone is dependent on the altitude of the perturbation. Ozone increases at altitudes near the tropopause produce the largest increases in RF because of the higher tem5 perature difference between surface and emission altitude. The spatial distribution of $\mathrm{NO}_{\mathrm{x}}$ emissions and therewith ozone vertical profiles of several ozone sources are very different. Industry, road traffic and ships especially emit in the northern mid-latitudes at low levels, while lightning, for example, emits especially in the tropical mid to upper troposphere. Therefore the ozone RF per unit column change differs significantly 10 between individual $\mathrm{NO}_{\mathrm{x}}$ sources.

Previous studies have concentrated on ozone changes between present-day and the preindustrial area or between a future time slice and the preindustrial area, in most cases for the total of all anthropogenic precursor emission sources (e.g. Gauss et al., 2006). In the present paper we address the development in time of ozone change 15 contributions, including their radiative forcing, from individual $\mathrm{NO}_{\mathrm{x}}$ emission sources. Analysis is based on transient simulations with a coupled chemistry climate model (CCM) covering the period between 1960 and 2019. A detailed description of the model and experimental set up is given in Sect. 2. The ozone column of different ozone sources and the resulting RF are described in Sect. 3. Uncertainties are discussed

20 in Sect. 4. Special emphasis is given to saturation and additing effects, which are discussed in Sects. 5.1 and 5.2, respectively.

\section{Model description and experimental set up}

The applied global climate-chemistry model E39/C (Hein et al., 2001) consists of the climate model ECHAM4.L39(DLR) (Land et al., 1999) coupled to the chemistry module CHEM (Steil et al., 1998). The climate model is a derivate of the standard ECHAM4 model (Roeckner et al., 1996), with a higher vertical resolution especially at tropopause levels to better represent processes and gradients in this region. ECHAM4 is a spectral

\section{Attribution of ozone radiative forcing trend to individual $\mathrm{NO}_{\mathrm{x}}$ sources}

K. Dahlmann et al.

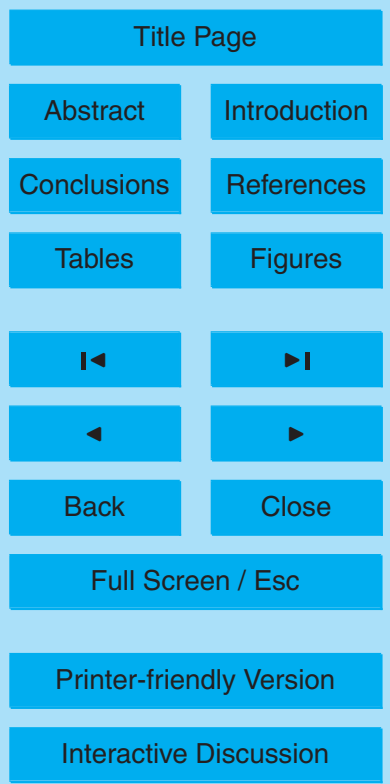


atmosphere general circulation model, based on the primitive equations.

The chemistry module CHEM includes homogeneous and heterogeneous stratospheric reactions, as well as the tropospheric background chemistry $\mathrm{CH}_{4}-\mathrm{CO}-\mathrm{NO}_{\mathrm{x}}-$ $\mathrm{HO}_{\mathrm{x}}-\mathrm{O}_{3}$. A total of 37 species and 107 reactions are applied, however, NMHC chem-

5 istry is not included. The model is running as a full interactive CCM, e.g. the hydrological cycle are directly coupled to the radiation and chemistry scheme, photolysis scheme, wet deposition and lightning. The model system has been intensively validated against measurements including a variety of international validation activities (e.g. Brunner et al., 2003, 2005; Austin et al., 2003; Shine et al., 2003) and has been 10 applied for a variety of scientific questions with regard to the future development of the ozone layer (Schnadt et al., 2002; Dameris et al., 2006), air traffic impacts (Grewe et al., 2002, and references therein), etc.

An ensemble of transient simulations for the recent past (1960 to 1999) and for the future (2000 to 2019) are used to calculate the ozone fields of different sources. For 15 a detailed description of the simulation of the past see Dameris et al. (2005) and for the future see Dameris et al. (2006).

Essential for the purpose addressed in this paper is the inclusion of a $\mathrm{NO}_{\mathrm{x}}$-ozone tracking diagnostic for individual sources in the E39/C simulations (Grewe, 2004) for which all emission sources for $\mathrm{NO}_{\mathrm{x}}$ are specified (lightning, biomass burning, soils, industry, road traffic, ships, air traffic and stratospheric $\mathrm{N}_{2} \mathrm{O}$ degradation). To each of these 8 sources a $\mathrm{NO}_{y}$ tracer is assigned in addition to the chemical species in the module $\mathrm{CHEM}$, which receives its specific emission and $\mathrm{NO}_{\mathrm{y}}$ loss terms proportional to the total $\mathrm{NO}_{\mathrm{y}}$ loss (Grewe, 2007). To each $\mathrm{NO}_{\mathrm{y}}$ tracer an ozone tracer is assigned, which experiences an ozone production proportional to the ratio of specific $\mathrm{NO}_{y}$ to total $\mathrm{NO}_{\mathrm{y}}$ concentration multiplied by the total ozone production via the reaction of $\mathrm{NO}+\mathrm{HO}_{2} \rightarrow \mathrm{NO}_{2}+\mathrm{OH}$. A further ozone tracer is included to account for ozone production by $\mathrm{O}_{2}$ photolysis (mainly in the stratosphere). Grewe (2004) compared two approaches to calculate the contribution of $\mathrm{NO}_{\mathrm{x}}$ emissions to ozone: the tagging method and calculation of individual ozone perturbations by dedicated simulations for

\section{Attribution of ozone radiative forcing trend to individual $\mathrm{NO}_{x}$ sources}

K. Dahlmann et al.

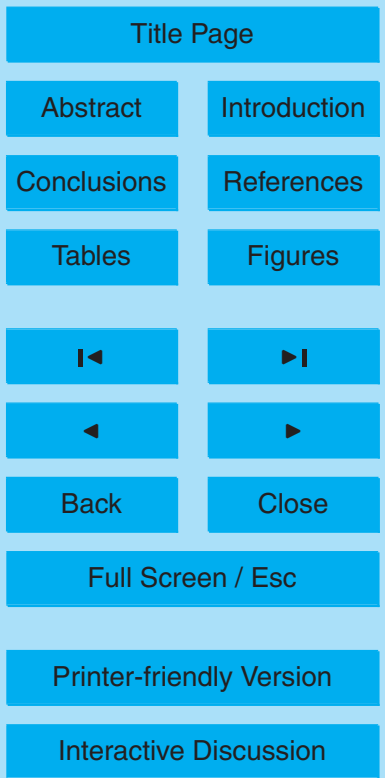


individual $\mathrm{NO}_{\mathrm{x}}$ emissions. With latter, the ozone concentration response could not be fully explained, due to non-linearities in the chemistry. Hence, a downscaling of the emissions and subsequent upscaling of the ozone response derived was necessary in case of individual perturbation simulations. Differences occurred in the tropopause 5 region. However, both approaches largely agreed if trends in ozone are attributed to trends in emissions, as trends are generally smaller than background distribution from some emission sector. Emissions of $\mathrm{NO}_{\mathrm{x}}$ are either prescribed (biomass burning, road traffic, ships, soils, industry, and air traffic) or calculated on-line (lightning, $\mathrm{N}_{2} \mathrm{O}$ degradation). Lighting $\mathrm{NO}_{\mathrm{x}}$ emissions are calculated based on the strength of the convective 10 mass flux and depth of convective clouds (Grewe et al., 2001).

The development of individual $\mathrm{NO}_{\mathrm{x}}$ emissions from different tropospheric sources from 1960-2019 is presented in Fig. 1a. The growth of anthropogenic $\mathrm{NO}_{\mathrm{x}}$ emissions is based on economic scenarios of development of GDP (gross domestic product) in respective geographical regions. Industry has shown the highest $\mathrm{NO}_{\mathrm{x}}$ emissions ever 15 since the 1960s and further rapid increase is expected until 2019. The second largest emitter of $\mathrm{NO}_{\mathrm{x}}$ is road traffic. The $\mathrm{NO}_{\mathrm{x}}$ emissions of road traffic have increased in the past (1960-2003) proportional with industry. Since 2004 the increase of road traffic $\mathrm{NO}_{\mathrm{x}}$ emissions continues to be proportional to industrial emissions only in developing regions like Latin America, Africa, China, Eastern Europe, CIS (Commonwealth of Independent States), Middle East, India and Southeast Asia (Fig. 1b), with highest growth rates in Southeast Asia, India, China and Africa. In industrial regions like USA, Canada, Japan, Oceania and Europe a slow decrease of $\mathrm{NO}_{\mathrm{x}}$ emission is assumed due to the use of reduction mechanism like catalytic converters (Matthes, 2003). Likewise, due to projected emission reductions by international regulations the $\mathrm{NO}_{\mathrm{x}}$ emis25 sions from shipping can be expected to decrease beyond 2005, too (Eyring et al., 2005; $\mathrm{H}$. W. Köhler, personal communication). The increase of $\mathrm{NO}_{\mathrm{x}}$ emission from air traffic is similarly fast as that of industry but with a much lower absolute value. Emissions from air traffic are only about $2 \%$ of industry emissions (for a better visibility the emissions of air traffic are multiplied by a factor of 10 in Fig. 1a). Natural sources like lightning

\section{Attribution of ozone radiative forcing trend to individual $\mathrm{NO}_{\mathrm{X}}$ sources}

K. Dahlmann et al.

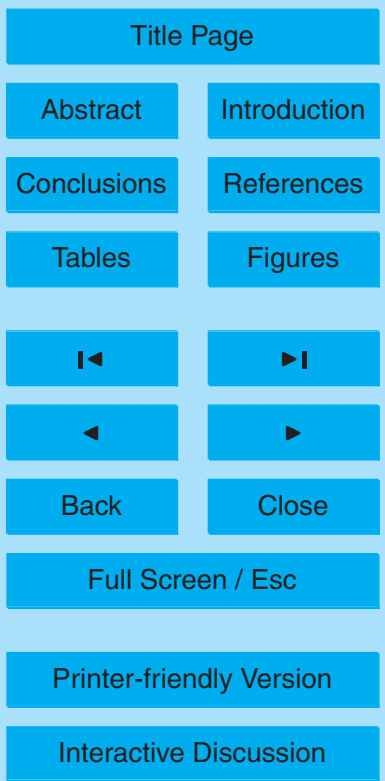


and soils as well as biomass burning display an almost constant value during the time period considered here.

An average annual cycle of each ozone field and for each decade of the transient simulations has been taken from the CCM as an input for a subsequent RF calculation.

5 The decadal means are calculated from 1960 to 1969, 1970 to 1979, etc. The RF of an individual ozone source is calculated as difference between RF of the complete ozone field and the RF of a disturbed field (difference between complete field and ozone field of the corresponding source), thus an inverse RF calculation is used. The RFs are calculated using the ECHAM4 radiation scheme in an extra one year simulation with 10 three month spinup.

The stratosphere adjusted RF at the tropopause is calculated, according to the fixed dynamic heating concept, as adopted for use in ECHAM4 by Stuber et al. (2001). This method has already been applied several times for idealised and realistic ozone perturbations (Stuber et al., 2001, 2005). The ECHAM4 radiation scheme performs 15 well for tropospheric ozone but shows a tendency to underestimate the ozone RF for stratospheric perturbations (Forster et al., 2001).

\section{Trends in ozone and ozone RF}

\subsection{Ozone}

The global distribution of column ozone for the different sources of the 1990s is presented in Fig. 2. In order to enable use of the same colour set for all sources $\mathrm{N}_{2} \mathrm{O}$ degradation and $\mathrm{O}_{2}$ photolysis have been multiplied with 0.1 and 0.01 , respectively. Anthropogenic sources like road traffic, air traffic, ships and industry show higher ozone columns in the Northern- than in the Southern-Hemisphere due to the higher $\mathrm{NO}_{\mathrm{x}}$ emissions in the Northern Hemisphere. Although the $\mathrm{NO}_{\mathrm{x}}$ emissions of road traffic and industry take place over land only, the ozone column over oceans is also affected because of $\mathrm{NO}_{\mathrm{x}}$ and ozone transport by midlatitude westerly winds. The ozone column

\section{Attribution of ozone radiative forcing trend to individual $\mathrm{NO}_{x}$ sources}

K. Dahlmann et al.

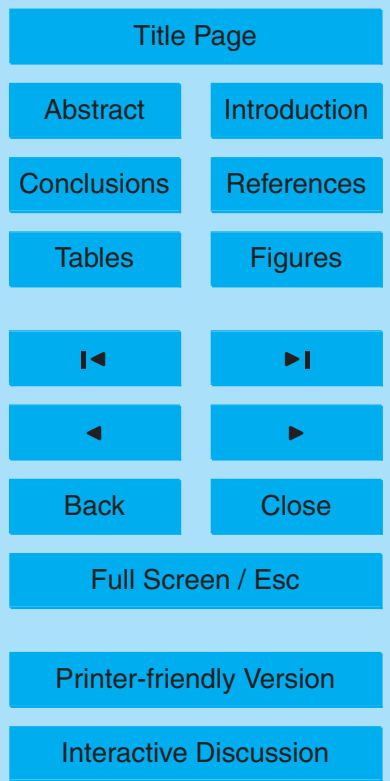

\section{7}


resulting for $\mathrm{NO}_{\mathrm{x}}$ emissions of soils shows a broad maximum between about $60^{\circ} \mathrm{N}$ and $30^{\circ} \mathrm{S}, \mathrm{NO}_{\mathrm{x}}$ emissions from biomass burning cause an ozone maximum in South Africa due to natural and anthropogenic fires in the rainforest.

Lightning primary occurs in tropical regions with deep convection. In those regions 5 the $\mathrm{HNO}_{3}$ wash-out is rather high and hence the highest ozone columns value to lightning can be found rather in the outflow regions of main convective activity: Lightning $\mathrm{NO}_{\mathrm{x}}$ is transported downwind from regions with convective activity into regions with large-scale subsidence characterized by clear-sky conditions and UV radiance, which produce very high ozone columns. This finding is consistent with observations as high $10 \mathrm{NO}_{\mathrm{x}}$ levels in the outflow of mesoscale convection systems have been recently reported by Huntrieser et al. (2007).

The highest ozone column caused by $\mathrm{N}_{2} \mathrm{O}$ degradation and $\mathrm{O}_{2}$ photolyses, respectively, are at higher latitudes especially in the north, although highest stratospheric ozone production rates takes place in the tropics. Since the lifetime is small in trop15 ical regions, most of the ozone is destroyed when transported to higher latitudes via Brewer-Dobson-Circulation and mixed with ozone from extratropical high altitudes (Grewe, 2006). At higher latitudes the ozone lifetime is quite large and a combination of local ozone production and transported ozone from the tropics causes the higher ozone columns at these latitudes.

20 Figure $3 \mathrm{a}$ shows the trend in global mean column ozone of all tropospheric $\mathrm{NO}_{\mathrm{x}}$ sources between 1960 and 2019. Although lightning contributes relatively small global mean $\mathrm{NO}_{\mathrm{x}}$ emission, similar to biomass burning or soils, the total ozone column component is about three times larger than respective components from biomass burning or soils $\mathrm{NO}_{\mathrm{x}}$ emission. A similar behaviour can be seen in the ozone column of air

column of air traffic and ships in the 2000s is just equal. The reason for these differences in production efficiency will be further discussed below.

Lightning causes a relative large ozone column (12DU) in comparison with groundbased anthropogenic sources like road traffic and ships (1-5DU). These column con-

\section{Attribution of ozone radiative forcing trend to individual $\mathrm{NO}_{x}$ sources}

K. Dahlmann et al.

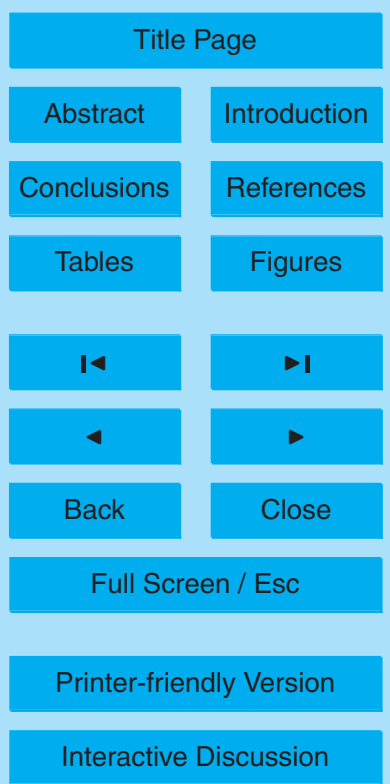

\section{8}


tributions are located in the troposphere, while ozone column contributions from $\mathrm{N}_{2} \mathrm{O}$ degradation and $\mathrm{O}_{2}$-Photolyses are stratospheric, with contributions of around 40 and $210 \mathrm{DU}$, respectively. While soils, biomass burning and lightning show a decreasing ozone column since the 1960s, Industry and air traffic show an increasing ozone col5 umn because of the rapidly increasing $\mathrm{NO}_{x}$ emission. Road traffic and ship emissions increase until 2005 and decrease afterwards due to the decreasing $\mathrm{NO}_{\mathrm{x}}$ emissions. The ozone column resulting from $\mathrm{NO}_{x}$ emission through $\mathrm{N}_{2} \mathrm{O}$ degradation (not shown) increases due to increasing $\mathrm{N}_{2} \mathrm{O} . \mathrm{O}_{2}$ photolyses ozone column (not shown) decreases from 1970 to 2010 mainly resulting from emissions of chlorofluorocarbons (CFCs) lead10 ing to ozone destruction (e.g. WMO, 2003; Dameris et al., 2006).

To make it more clear why the relative ozone change from some sources is not given by the relative contribution to the total $\mathrm{NO}_{\mathrm{x}}$ emission, the ozone production efficiency is calculated, which shows how many ozone molecules are produced per molecule $\mathrm{NO}_{\mathrm{x}}$. The ozone production efficiency of lightning and air traffic is much higher than 15 that of groundbased sources like road traffic, ships, biomass burning, soils and industry (Fig. 3b). While lightning produces about 100 molecules $\mathrm{O}_{3}$ per molecule $\mathrm{NO}_{x}$, air traffic produce about 50 and the other sources between 10 and 30 molecules $\mathrm{O}_{3}$ per molecule $\mathrm{NO}_{\mathrm{x}}$. The reason for a higher ozone production efficiency of lightning and air traffic is the higher amount of UV radiance at higher altitudes. The reason for the differences of ground based sources is the strong dependency of ozone production efficiency of the background $\mathrm{NO}_{\mathrm{x}}$ (Fig. 4). The $\mathrm{NO}_{\mathrm{x}}$ value with maximum ozone production is dependent of background $\mathrm{O}_{3}, \mathrm{H}_{2} \mathrm{O}$ and $\mathrm{CO}$ (Grooß et al., 1998) and lies normally between 0.2 and $0.4 \mathrm{ppbv}$, but can be up to $5 \mathrm{ppbv}$ (Lin et al., 1988). The ozone production efficiency at a low background $\mathrm{NO}_{\mathrm{x}}$ levels is very small and increases very fast 25 with increasing background. If a certain amount of $\mathrm{NO}_{x}$ is exceeded, an increase of $\mathrm{NO}_{x}$ causes a decrease of ozone production efficiency and at last an ozone depletion. Thus emissions in polluted areas cause lower ozone production efficiency than in remote areas. The strong increase of the ozone production efficiency of air traffic from 1960-1980 can be explained with the above mentioned relation between back-

\section{Attribution of ozone radiative forcing trend to individual $\mathrm{NO}_{x}$ sources}

K. Dahlmann et al.

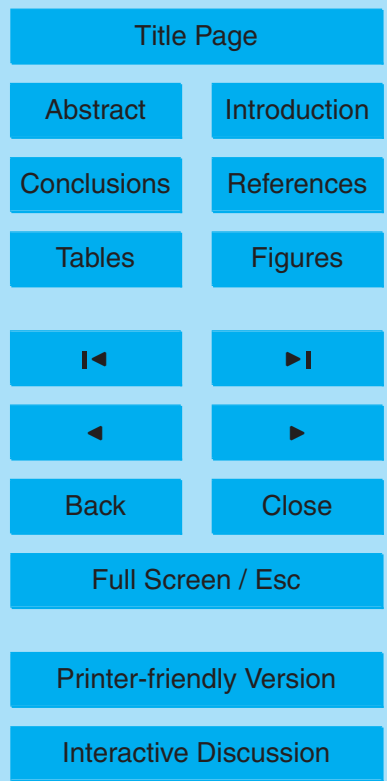

\section{9}


ground $\mathrm{NO}_{\mathrm{x}}$ and ozone production efficiency. In the 1960 s a very low background $\mathrm{NO}_{\mathrm{x}}$ of less than $0.02 \mathrm{ppbv} \mathrm{NO}_{\mathrm{x}}$ in higher altitudes causes only a small ozone production, while the increasing background in the 1990s in our simulation causes an increasing ozone production. The ozone production efficiency of industry is lower than that of 5 other ground based sources because the $\mathrm{NO}_{\mathrm{x}}$ emissions take place only in already polluted areas with background values of about 1 ppbv where increasing $\mathrm{NO}_{\mathrm{x}}$ values causes a decreasing ozone production efficiency. Whereas soils and biomass burning emits mainly in remote areas with about 0.2 ppbv and ship, air traffic and road traffic emissions are placed in remote as well as polluted areas. The ozone production 10 efficiency of soils $\mathrm{NO}_{\mathrm{x}}$ emissions is higher in comparison to emissions from biomass burning, because soil emissions peak in the northern midlatitudes summer when the ozone production is enhanced. The enhanced soils emissions in northern midlatitudes in summer are fertilizer induced emissions in agricultural regions (Steinkamp et al., 2009).

15 The ozone production efficiency of almost all surface sources show a decrease with time, consistent with what has been shown in Lamarque et al. (2005). The reason for this is the increasing overall $\mathrm{NO}_{\mathrm{x}}$ level in our simulation which causes the above mentioned saturation effect for each of the individual contributions. An exception is the ozone production efficiency of road traffic which shows a little increase since 2005. The reason for this is the assumed future scenario implying that $\mathrm{NO}_{\mathrm{x}}$ emissions of road traffic only increase in nonindustrial (remote) regions but decrease in industrial (polluted) regions beyond 2005 (see Fig. 1b). Uno et al. (2007) showed strong increase of $\mathrm{NO}_{2}$ from 1996 to 2004 over Asia, while Konovalov et al. (2008) shows different development over Europe in this period. The $\mathrm{NO}_{\mathrm{x}}$ emissions over Germany and Great Britain e.g. decreases, but the emissions over Greece and Spain shows a slight increase.

\subsection{Radiative forcing}

The temporal development from 1960 to 2019 of ozone RF from tropospheric sources as derived from the concentration changes discussed in the last section is shown in

\section{Attribution of ozone radiative forcing trend to individual $\mathrm{NO}_{x}$ sources}

K. Dahlmann et al.

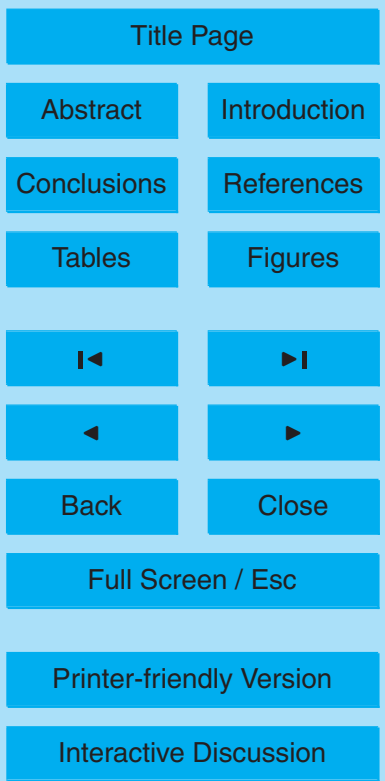


Fig. 5. Temporal correlation between RF change and ozone column change is rather close for each component. The highest RF $\left(510-550 \mathrm{~mW} / \mathrm{m}^{2}\right)$ as well as the highest ozone column $(12 \mathrm{DU})$ is provided by lightning. The lowest $R F\left(30 \mathrm{~mW} / \mathrm{m}^{2}\right)$ as well as the lowest ozone column (1DU) is contributed by ships and air traffic. However, the 5 relative contribution of some components to the ozone column does not fully predict its relative importance for the ozone RF. This holds especially for stratospheric sources: Although the ozone columns of $\mathrm{N}_{2} \mathrm{O}$ degradation and $\mathrm{O}_{2}$ photolysis with 40 and $210 \mathrm{DU}$ are very high, they produce a relative small RF of about $350 \mathrm{~mW} / \mathrm{m}^{2}$ (not shown).

In the purpose of studying how effectively an ozone source perturbs the radiation 10 balance we display the specific RF per DU (RF efficiency) in Fig. 6. While tropospheric sources show a similar RF efficiency ranging between 38 and $46 \mathrm{~mW} /\left(\mathrm{m}^{2} \mathrm{DU}\right)$, $\mathrm{N}_{2} \mathrm{O}$ degradation and $\mathrm{O}_{2}$ photolysis have smaller net RF efficiencies of 9 and $2 \mathrm{~mW} /\left(\mathrm{m}^{2} \mathrm{DU}\right)$, respectively (not shown). The main reason for the low net RF efficiency of $\mathrm{N}_{2} \mathrm{O}$ degradation and $\mathrm{O}_{2}$ photolysis is the negative shortwave part which 15 compensates almost the longwave part of RF. The shortwave RF is negative because the extra solar energy that is absorbed at UV and visible wavelengths by the added ozone within the stratosphere is no longer available for absorption by the tropospheresurface system (Lacis et al., 1990).

Except for the difference in sign, the shortwave RF efficiency of ozone from $\mathrm{N}_{2} \mathrm{O}$ 20 degradation and $\mathrm{O}_{2}$ photolysis are almost in the same range than that of tropospheric sources $\left(8-13 \mathrm{~mW} /\left(\mathrm{m}^{2} \mathrm{DU}\right)\right.$, not shown). The longwave RF efficiency of stratospheric sources $\left(15-17 \mathrm{~mW} /\left(\mathrm{m}^{2} \mathrm{DU}\right)\right.$, not shown) are only half of the tropospheric values (27$36 \mathrm{~mW} /\left(\mathrm{m}^{2} \mathrm{DU}\right)$, not shown). It is mainly the temperature contrast between the ground and the perturbed layer temperatures that accounts for the variation in the ozone vertical greenhouse efficiencies profile (Lacis et al., 1990). Above the tropopause the longwave RF decreases in strength (but remains positive) as the ozone increment is radiating with higher temperature. In addition, the reduced pressure broadening with increasing height also tends to decrease the greenhouse efficiency (Ramanathan et al., 1976).

\section{Attribution of ozone radiative forcing trend to individual $\mathrm{NO}_{x}$ sources}

K. Dahlmann et al.

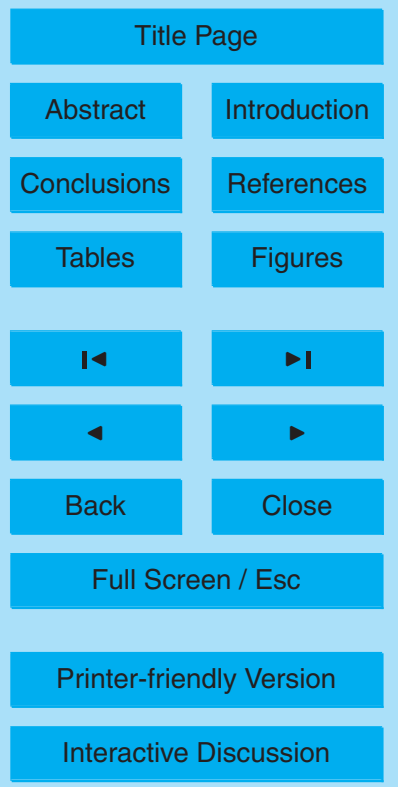

16141 
The net RF efficiency of the tropospheric sources is shown in Fig. 6 as a function of time. The efficiency values vary more strongly between the individual effects than they do over time for each effect. Since 1980 the sources may grouped into three parts: high RF efficiency (lightning), intermediate RF efficiency (soils, biomass burning and air 5 traffic) and low RF efficiency (ships, road traffic and industry). The difference in net RF efficiency is mainly controlled by the longwave forcing (greenhouse effect). Due to the dependency of the greenhouse effect on the temperature of the absorber (see above) the RF efficiency is largest for ozone changes near the tropopause (Lacis et al., 1990). Beside the altitude dependency there is a latitude dependency: Due to the fact that the 10 longwave emission is proportional to $T_{\mathrm{s}}^{4}$ (surface temperature), the same temperature difference at higher temperatures produces a higher greenhouse effect than at lower temperatures. Hence, the longwave RF efficiency in the tropics is higher than at high latitudes. The RF efficiency depending on the latitude is presented in Fig. 7. The RF efficiency at low latitudes (about $50 \mathrm{~mW} /\left(\mathrm{m}^{2} \mathrm{DU}\right)$ ) is almost three times higher than at 15 high latitudes (about $15 \mathrm{~mW} /\left(\mathrm{m}^{2} \mathrm{DU}\right)$ ). This confirms earlier results (Berntsen et al., 1997) of the increase of ozone RF with decreasing latitude. The effect of emission at higher levels can still be noticed in Fig. 7. Lightning and air traffic have a somewhat higher RF efficiency than the groundbased sources for all latitudes. However, while the difference of RF efficiency between equator and pole is about $30 \mathrm{~mW} /\left(\mathrm{m}^{2} \mathrm{DU}\right)$, the difference of RF efficiency between ground based sources like soils and sources in higher altitudes like lightning is only up to $10 \mathrm{~mW} /\left(\mathrm{m}^{2} \mathrm{DU}\right)$. The latitude effect is hence about three time larger than the altitude effect. The RF efficiency of lightning ozone is higher than that of other sources because the altitude effect as well as the latitude effect are working in the same direction, i.e. towards higher specific RF. Aircraft have an intermediate RF efficiency since the emissions take place in a higher altitudes but in mid and high latitudes. The RF efficiency of soils and biomass burning is higher than that of road traffic, ships and industry because the emission take place mainly in tropical regions.

Variation of ozone RF can be explained by a combination of $\mathrm{NO}_{\mathrm{x}}$ emission, ozone

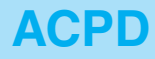

9, 16131-16162, 2009

\section{Attribution of ozone radiative forcing trend to individual $\mathrm{NO}_{x}$ sources}

K. Dahlmann et al.

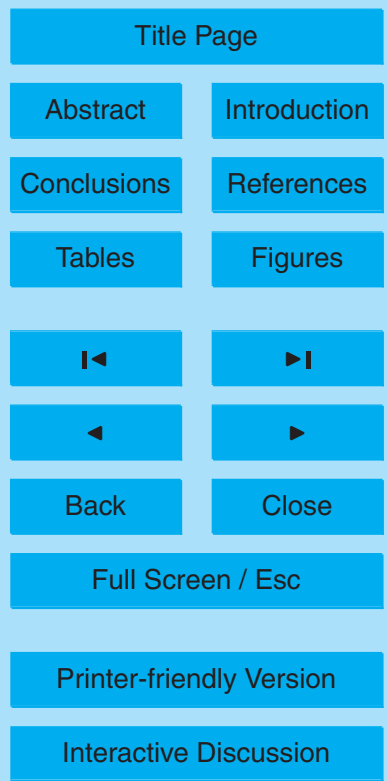


production efficiency and RF efficiency as discussed in the previous sections. To summarise the reasons for the RF trend seen in Fig. 5 we show this three effects as fraction of 2010-2019 values to 1960-1969 values in Fig. 8. The product of those effects equates to the fraction of $10 \mathrm{~s}$ RF to $60 \mathrm{~s}$ RF. Trend in ozone RF of lightning emissions

5 is negative due to decreasing emissions and RF efficiency (Grewe, 2009). Despite the decreasing ozone production and RF efficiency of industry, road traffic and shipping ozone RFs increase due to the increasing emissions of these sectors. The positive trend in ozone RF of air traffic is due to increasing emissions as well as increasing ozone production efficiency and RF efficiency. The trend in biomass burning RF is 10 almost zero because the increasing emissions are compensated by chemical and radiational saturation effects. Although soil emissions are constant the RF decreases due to decreasing ozone production efficiency and RF efficiency.

\section{Uncertainties and discussion}

Our analysis is based on the calculation of ozone distributions with an online tagging 15 mechanism (Grewe, 2004), representing an accounting system for $\mathrm{NO}_{y}$ and $\mathrm{O}_{3}$ contributions from individual $\mathrm{NO}_{x}$ sources in addition to stratospheric ozone production. This methodology has a large advantage: It is strictly additive and completely explains the simulated total $\mathrm{NO}_{\mathrm{x}}$ and ozone fields. I.e. the ozone field is completely partitioned, except for numerical diffusion caused by the transport scheme. Additivity and complete partition in this respect means that the sum of tagged ozone fields from two sources equals the ozone due to the sum of both emissions and that the sum of all tagged ozone fields equals the ozone field, respectively. Other approaches (Hoor et al., 2008) use small changes in the emissions, e.g. by $5 \%$, in order to calculate the impact of emissions on atmospheric concentrations. This ensures additivity, but not necessarily complete partitioning. As mentioned in Sect. 2 the tagging method may lead to larger changes in the upper troposphere and lower stratosphere (Grewe, 2004), though the excess remains small compared to the background field. The impact on radiative forc-

\section{Attribution of ozone radiative forcing trend to individual $\mathrm{NO}_{x}$ sources}

K. Dahlmann et al.

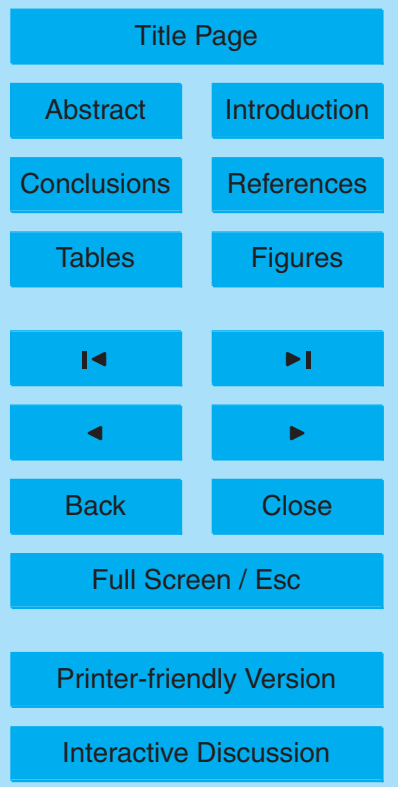


ing can be significant, however.

The total anthropogenic ozone forcing is calculated in this paper to be $0.52 \mathrm{~mW} / \mathrm{m}^{2}$, which compares well with the IPCC estimate of $0.35(0.25$ to 0.65$) \mathrm{W} / \mathrm{m}^{2}$. The contribution from individual sectors is within the range of other modelling studies with respect 5 to lightning (Toumi et al., 1996), aircraft (Sausen et al., 2005; Fuglestvedt et al., 2008) and ship emissions (Fuglestvedt et al., 2008). With regard to biomass burning emissions, the emission strength varies largely among other studies. Scaling of the results by Unger et al. (2008) to the same emission strength leads to an agreement in the range of $25 \%$. Road traffic emissions are assumed to be larger in our study compared

10 to Hoor et al. (2008); Granier and Brasseur (2003); Fuglestvedt et al. (2008). The response to ozone and RF are similar to Fuglestvedt et al. (2008): They estimated (see their supporting materials) 25 molecules ozone per emitted $\mathrm{NO}_{\mathrm{x}}$ molecule and $45 \mathrm{~mW} /\left(\mathrm{m}^{2} \mathrm{DU}\right)$, which compares well with our values (Figs. $3 \mathrm{~b}$ and 6$)$.

Some of the remaining discrepancies occur due to the consideration of the $\mathrm{NO}_{\mathrm{x}}$ $15 \mathrm{HO}_{\mathrm{x}}-\mathrm{CO}-\mathrm{CH}_{4}$ chemistry and emissions, only. Road traffic NMHC emissions (which are not considered in E39/C) enhance the long-range transport of nitrogen compounds via formation of additional PAN (Matthes et al., 2007). However, the less confined change pattern expected due to PAN formation and the shorter ozone lifetime caused by an increase in $\mathrm{HO}_{2}$ due to $\mathrm{NMHC}$ chemistry are counteracting processes. NMHC chemistry 20 is not included in the present simulation and both processes somehow compensate, but for the wrong reason.

\section{Nonlinearities}

\subsection{Saturation effects}

The analysis of the trend of the RF produced per DU ozone (RF efficiency, Fig. 6) showed that this efficiency decreases with time. Since 1980 the RF efficiency of almost all sources decreases. By the 2010 s it is about $2-3 \%$ lower than during the 1980 s,

\section{ACPD}

9, 16131-16162, 2009

\section{Attribution of ozone radiative forcing trend to individual $\mathrm{NO}_{\mathrm{x}}$ sources}

K. Dahlmann et al.

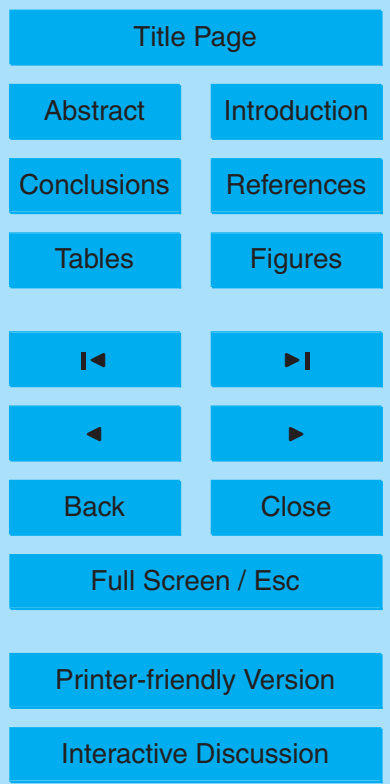


except for the aviation and road traffic contributions. In this section we present and discuss results of dedicated radiative forcing calculations in order to quantify a potential saturation effect in the radiative forcing dependent on the background ozone level.

To this end, the radiative forcing of the tropospheric ozone distribution of the 1990s 5 was calculated with the background ozone gradually increasing. As RF calculation is inverse (see Sect. 2) the same ozone distribution is subtracted of differing background ozone fields. Six different radiative forcings were performed using an ozone background amplified by factors one, two, three, four, five and six. The results are displayed in Fig. 9. The higher the background ozone the lower the resulting RF efficiency.

10 This effect is stronger for the longwave forcing than for the shortwave forcing, because ozone absorbs longwave radiation only in a small band which is faster saturated than the wide band of ozone absorption of shortwave radiation. The nonlinear behaviour of the net RF is dominated by the longwave component.

\subsection{Additivity}

15 In this section we study whether the nonlinear saturation effect discussed above limits the additivity of the RF of a number of different components. Hence, we did an additional RF calculation for the sum of all tropospheric sources and for the sum of the two stratospheric sources. This forcing of the sum of contributions is compared with the sum of all separate forcings as displayed in Fig. 5. The comparison employs the 201990 s conditions as an example. As RF is calculated inverse, the RF of the sum of the stratospheric sources is calculated with double background ozone, because otherwise spurious negative ozone residuals might have caused a calculation crash.

In Fig. 10 the longwave, shortwave and net RF for both calculation methods are shown. While the shortwave forcing of tropospheric sources (Fig. 10a) doesn't show 25 any substantial deviation from perfect additivity, the longwave forcing of the sum of separately calculated RF is about $0.15 \mathrm{~W} / \mathrm{m}^{2}$, i.e. $10 \%$, lower than the radiative forcing of the sum of ozone changes. For the stratospheric sources (Fig. 10b) the separately calculated net RF is almost equal to the RF of the sum of both sources, due to the

\section{Attribution of ozone radiative forcing trend to individual $\mathrm{NO}_{\mathrm{x}}$ sources}

K. Dahlmann et al.

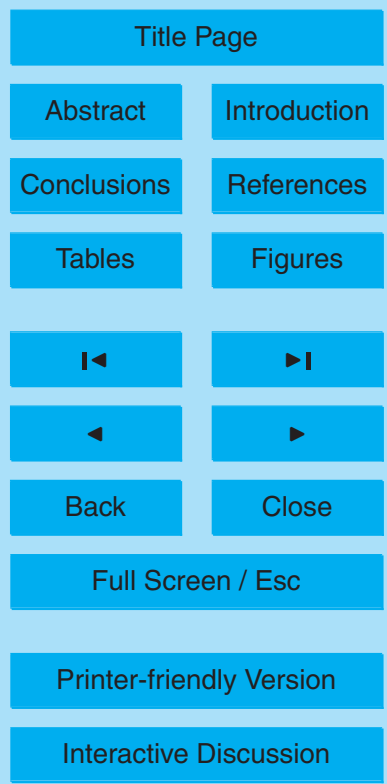

16145 
fact that both forcings are about $0.1 \mathrm{~W} / \mathrm{m}^{2}$ higher but shortwave forcings are negative. The main reason for the nonlinearity in the tropospheric case is the saturation effect described in Sect. 5.1: In case of an individual calculation for each component, the background ozone levels is always higher than it is in case of one calculation for the

5 sum of components. As in Sect. 5.1 the higher background ozone causes a saturation effect and therewith smaller RF. As a result, the RF of anthropogenic sources are smaller if the RFs of different sources are totalised than the RF of one calculation for the sum of components.

\section{Conclusions}

10 In this paper the temporal development of atmospheric ozone and its radiative forcing has been analysed with respect to the contributions of individual $\mathrm{NO}_{\mathrm{x}}$ emission sources. The ozone production efficiency (ozone production per molecule $\mathrm{NO}_{\mathrm{x}}$ ) and therewith the produced ozone column is strongly dependent on the emission level and to a lower extent to the background $\mathrm{NO}_{\mathrm{x}}$ level. For example, one $\mathrm{NO}_{\mathrm{x}}$ molecule emit15 ted by lightning in relatively high altitudes can produce about 100 molecules $\mathrm{O}_{3}$, while one $\mathrm{NO}_{x}$ molecule emitted by industry can only produce about 10 molecules $\mathrm{O}_{3}$. The dependency of background $\mathrm{NO}_{x}$ can also be seen, e.g., in the different ozone production efficiency of industry and soils. Soils emissions occur in remote areas of relatively low background concentration and produce about three time more ozone than industry which emits in polluted areas.

The RF of tropospheric sources show a strong correlation with ozone column: a high ozone column causes a high RF. Different to the tropospheric sources, the stratospheric sources cause a very low RF relative to their high ozone column. The reason is the negative shortwave part of the RF (if solar absorption occurs above the tropopause) 25 which almost compensates the positive longwave forcing. Another reason for the low $\mathrm{RF}$ values of stratospheric sources in the mid stratosphere is the relative low longwave part caused by the temperature increase above the tropopause.

\section{Attribution of ozone radiative forcing trend to individual $\mathrm{NO}_{x}$ sources}

K. Dahlmann et al.

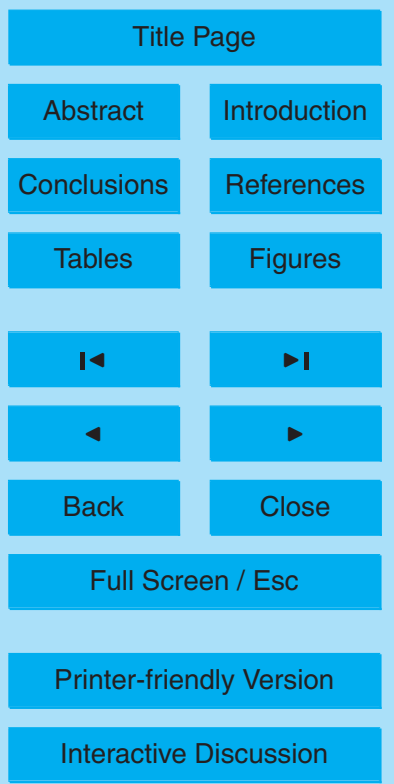


The longwave RF is dependent on the difference between the surface temperature and the temperature of the absorption altitude, respectively. So the longwave RF is dependent on the emission altitude because of the higher temperature difference of emission and absorption level as well as on the emission latitude due to the higher

5 emission temperature of the surface. The latitude effect is about three times larger than the altitude effect.

Additional to the modulating impact of latitude and altitude of the added ozone on the induced RF there is a saturation effect which causes a decreasing RF efficiency with increasing background ozone due to saturation of absorption bands. This satu10 ration effect is a reason for the occurrence of a nonlinearity effect. The nonlinearity effect causes differences of about $10 \%$ in RF between calculating several disturbances separately or together due to the different background $\mathrm{NO}_{\mathrm{x}}$.

The results show that changes in $\mathrm{NO}_{\mathrm{x}}$ emissions (1960-2019) control the RF changes for most sources. RF changes are slightly decreasing due to a changing 5 atmospheric composition (10-25\%) for all but the aircraft sources and due to RF saturation $(2-5 \%)$.

Acknowledgements. This work has been funded by the Integrated Project QUANTIFY of the EU 6th Framework Programme.

\section{References}

Austin, J., Shindell, D., Beagley, S. R., Brühl, C., Dameris, M., Manzini, E., Nagashima, T., Newman, P., Pawson, S., Pitari, G., Rozanov, E., Schnadt, C., and Shepherd, T. G.: Uncertainties and assessments of chemistry-climate models of the stratosphere, Atmos. Chem. Phys., 3, 1-27, 2003, http://www.atmos-chem-phys.net/3/1/2003/. 16135

Berntsen, T. K., Isaksen, I. S. A., Myhre, G., Fuglestvedt, J. S., Stordal, F., Alsvik Larsen, T., Freckleton, R. S., and Shine, K.: Effects of anthropogenic emissions on tropospheric ozone and its radiative forcing, J. Geophys. Res., 102, 28101-28126, 1997. 16142

Brunner, D., Staehelin, J., Rogers, H. L., Köhler, M. O., Pyle, J. A., Hauglustaine, D., Jourdain, L., Berntsen, T. K., Gauss, M., Isaksen, I. S. A., Meijer, E., van Velthoven, P., Pitari, G.,

\section{Attribution of ozone radiative forcing trend to individual $\mathrm{NO}_{x}$ sources}

K. Dahlmann et al.

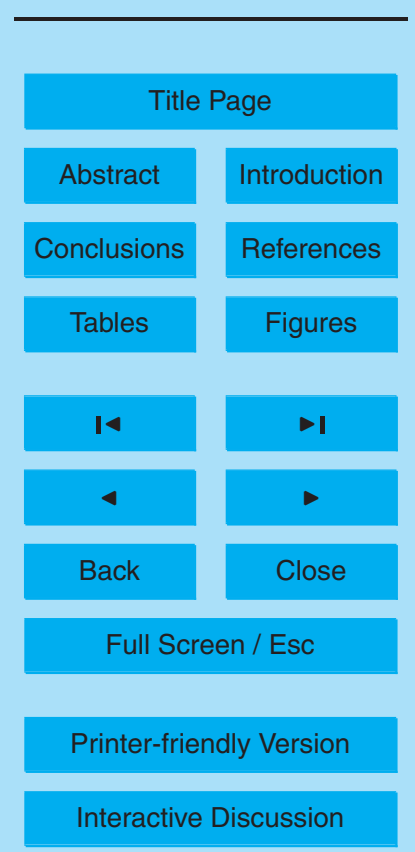


Mancini, E., Grewe, G., and Sausen, R.: An evaluation of the performance of chemistry transport models by comparison with research aircraft observations. Part 1: Concepts and overall model performance, Atmos. Chem. Phys., 3, 1609-1631, 2003,

http://www.atmos-chem-phys.net/3/1609/2003/. 16135

5 Brunner, D., Staehelin, J., Rogers, H. L., Köhler, M. O., Pyle, J. A., Hauglustaine, D. A., Jourdain, L., Berntsen, T. K., Gauss, M., Isaksen, I. S. A., Meijer, E., van Velthoven, P., Pitari, G., Mancini, E., Grewe, V., and Sausen, R.: An evaluation of the performance of chemistry transport models - Part 2: Detailed comparison with two selected campaigns, Atmos. Chem. Phys., 5, 107-129, 2005, http://www.atmos-chem-phys.net/5/107/2005/. 16135

Dameris, M., Grewe, V., Ponater, M., Deckert, R., Eyring, V., Mager, F., Matthes, S., Schnadt, C., Stenke, A., Steil, B., Brühl, C., and Giorgetta, M. A.: Long-term changes and variability in a transient simulation with a chemistry-climate model employing realistic forcing, Atmos. Chem. Phys., 5, 2121-2145, 2005, http://www.atmos-chem-phys.net/5/2121/2005/. 16135

Dameris, M., Matthes, S., Deckert, R., Grewe, V., and Ponater, M.: Solar cycle effect delays on15 set of ozone recovery, Geophys. Res. Lett., 33, L03806, doi:10.1029/2005GL024741, 2006. 16133, 16135, 16139

Dickinson, R. E.: Modelling climate changes due to carbon dioxide increases, in: Carbon Dioxide Review, edited by: Clerk, W. C., Oxford University Press, New York, 101-133, 1982. 16133

20 Eyring, V., Köhler, H., Lauer, A., and Lemper, B.: Emissions from international shipping: 2. Impact of future technologies on scenarios until 2050, J. Geophys. Res., 110, 17, doi:10. 1029/2004JD005620, 2005.

Eyring, V., Stevenson, D. S., Lauer, A., Dentener, F. J., Butler, T., Collins, W. J., Ellingsen, K., Gauss, M., Hauglustaine, D. A., Isaksen, I. S. A., Lawrence, M. G., Richter, A., Rodriguez, J. M., Sanderson, M., Strahan, S. E., Sudo, K., Szopa, S., van Noije, T. P. C., and Wild, O.: Multi-model simulations of the impact of international shipping on Atmospheric Chemistry and Climate in 2000 and 2030, Atmos. Chem. Phys., 7, 757-780, 2007, http://www.atmos-chem-phys.net/7/757/2007/. 16133

Fishman, J., Solomon, S., and Crutzen, P. J.: Observational and theoretical evidence in support of tropospheric ozone, Tellus, 31, 432-446, 1979. 16132

Forster, P. M. d. F., Ponater, M., and Zhong, W.-Y.: Testing broadband radiation schemes for their ability to calculate the radiative forcing and temperature response to stratospheric water vapour and ozone changes, Meteorol. Z., 10, 387-393, 2001. 16137

\section{ACPD}

9, 16131-16162, 2009

\section{Attribution of ozone radiative forcing trend to individual $\mathrm{NO}_{x}$ sources}

K. Dahlmann et al.

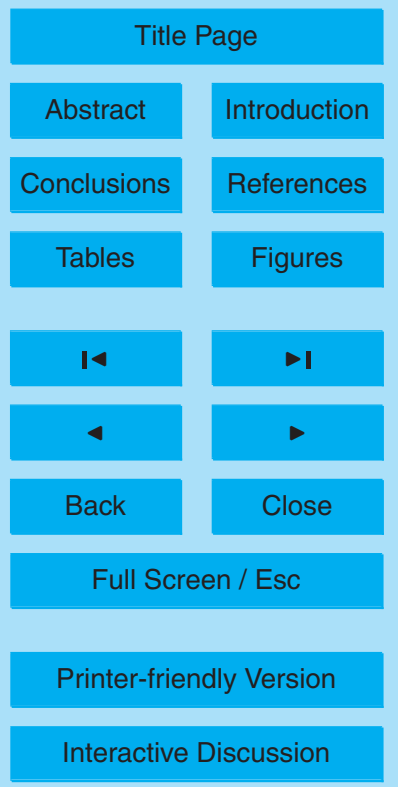


Fuglestvedt, J., Berntsen, T., Myhre, G., Rypdal, K., and Skeie, R. B.: Climate forcing from the transport sectors, PNAS, 105, 454-458, doi:10.1073/pnas.0702958104, 2008. 16144

Gauss, M., Myhre, G., Isaksen, I. S. A., Grewe, V., Pitari, G., Wild, O., Collins, W. J., Dentener, F. J., Ellingsen, K., Gohar, L. K., Hauglustaine, D. A., lachetti, D., Lamarque, F., Mancini, E., 5 Mickley, L. J., Prather, M. J., Pyle, J. A., Sanderson, M. G., Shine, K. P., Stevenson, D. S., Sudo, K., Szopa, S., and Zeng, G.: Radiative forcing since preindustrial times due to ozone change in the troposphere and the lower stratosphere, Atmos. Chem. Phys., 6, 575-599, 2006, http://www.atmos-chem-phys.net/6/575/2006/. 16134

Granier, C. and Brasseur, G.: The impact of road traffic on global tropospheric ozone, Geophys. Res. Lett., 30, 1086, doi:10.1029/2002GL015972, 2003. 16133, 16144

Grewe, V.: Technical Note: A diagnostic for ozone contributions of various $\mathrm{NO}_{\mathrm{x}}$ emissions in multi-decadal chemistry-climate model simulations, Atmos. Chem. Phys., 4, 729-736, 2004, http://www.atmos-chem-phys.net/4/729/2004/. 16135, 16143

Grewe, V.: The origin of ozone, Atmos. Chem. Phys., 6, 1495-1511, 2006,

15 http://www.atmos-chem-phys.net/6/1495/2006/. 16138

Grewe, V.: Impact of climate variability on tropospheric ozone, Science of the Total Environment, 374, 167-181, 2007. 16135

Grewe, V.: Impact of lightning on air chemistry and climate, in: Lightning: Principles, Instruments and Applications Review of Modern Lightning Research, edited by: Betz, H. D., Schumann, U., and Laroche, P., 524-551, Springer Verlag, The Netherlands, 2009. 16143

Grewe, V., Brunner, D., Dameris, M., Grenfell, J., Hein, R., Shindell, D., and Staehelin, J.: Origin and variability of upper tropospheric nitrogen oxides and ozone at northern mid-latidutes, Atmos. Environ., 35, 3421-3433, 2001. 16136

Grewe, V., Dameris, M., Fichter, C., and Sausen, R.: Impact of aircraft $\mathrm{NO}_{\mathrm{x}}$ emissions. Part 1: Interactivly coupled climate-chemistry simulations and sensitivities to climate-chemistry feedback, lightning and model resolution, Meteorol. Z., 3, 177-186, 2002. 16133, 16135

Grooß, J.-U., Brühl, C., and Peter, T.: Impact of aircraft emissions on tropospheric and stratospheric ozone. Part I: Chemistry and 2-D Model results, Atmos. Environ., 32, 3152-3184, 1998. 16139, 16156

30 Hansen, J., Sato, M., and Ruedy, R.: Radiative forcing and climate response, J. Geophys. Res., 102, 6831-6684, 1997. 16133

Hein, R., Dameris, M., Schnadt, C., Land, C., Grewe, V., Köhler, I., Ponater, M., Sausen, R., B. Steil, B., Landgraf, J., and Brühl, C.: Results of an interactively coupled atmospheric

\section{Attribution of ozone radiative forcing trend to individual $\mathrm{NO}_{\mathrm{x}}$ sources}

K. Dahlmann et al.

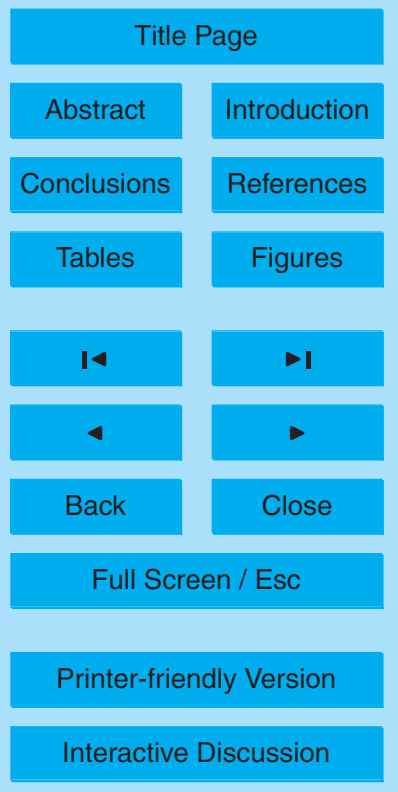


chemistry - general circulation model: Comparison with observations, Ann. Geophys., 19, 435-457, 2001, http://www.ann-geophys.net/19/435/2001/. 16134

Hoor, P., Borken-Kleefeld, J., Caro, D., Dessens, O., Endresen, O., Gauss, M., Grewe, V., Hauglustaine, D., Isaksen, I. S. A., Jöckel, P., Lelieveld, J., Meijer, E., Olivie, D., Prather, M., Schnadt Poberaj, C., Staehelin, J., Tang, Q., van Aardenne, J., van Velthoven, P., and Sausen, R.: The impact of traffic emissions on atmospheric ozone and $\mathrm{OH}$ : results from QUANTIFY, Atmos. Chem. Phys. Discuss., 8, 18219-18266, 2008,

http://www.atmos-chem-phys-discuss.net/8/18219/2008/. 16143, 16144

Huntrieser, H., Schlager, H., Roiger, A., Lichtenstern, M., Schumann, U., Kurz, C., Brunner, D., Schwierz, C., Richter, A., and Stohl, A.: Lightning-produced $\mathrm{NO}_{\mathrm{x}}$ over Brazil during TROCCINOX: airborne measurements in tropical and subtropical thunderstorms and the importance of mesoscale convective systems, Atmos. Chem. Phys., 7, 2987-3013, 2007, http://www.atmos-chem-phys.net/7/2987/2007/. 16138

IPCC: Climate Change: the IPCC Scientific Assessment, edited by: Houghton, J. T., Jenkins, 15 G. J., and Ephraums, J. J., Cambridge University Press, Cambridge, UK, 365 pp., 1990. 16133

IPCC:Climate Change 1992: The Supplementary Report to the IPCC Scientific Assessment, edited by: Houghton, J. T., Callander, B. A., and Varney, S. K., WMO/UNEP, Cambridge University Press, Cambridge, UK, 200 pp., 1992. 16133

IPCC:Climate Change 1994: Radiative Forcing of Climate Change, edited by: Houghton, J. T., Meira Filho, L. G., Bruce, J., Lee, H., Callander, B. A., Haites, E., Harris, N., and Maskell, K., Cambridge University Press, Cambridge, UK, 393 pp., 1995. 16133

IPCC:Aviation and the Global Atmosphere; A Special Report of IPCC Working Groups I and III, edited by: Penner, J. E., Lister, D. H., Griggs, D. J., Dokken, D. J., and McFarland, M., Cambridge University Press, Cambridge, UK, 393 pp., 1999. 16133

IPCC: Climate Change 2007: Synthesis Report. Summary for Policymakers., Tech. rep., Cambridge University Press, Cambridge, UK, 2007. 16133

Köhler, M. O., Rädel, G., Dessens, O., Shine, K. P., Rogers, H. L., Wild, O., and Pyle, J. A.: Impact of perturbations to nitrogen oxide emissions from global aviation, J. Geophys. Res.,

30 113, D11305, doi:10.1029/2007JD009140, 2008. 16133

Konovalov, I. B., Beekmann, M., Burrows, J. P., and Richter, A.: Satellite measurement based estimates of decadal changes in European nitrogen oxides emissions, Atmos. Chem. Phys., 8, 2623-2641, 2008, http://www.atmos-chem-phys.net/8/2623/2008/. 16140

\section{Attribution of ozone radiative forcing trend to individual $\mathrm{NO}_{\mathrm{x}}$ sources}

K. Dahlmann et al.

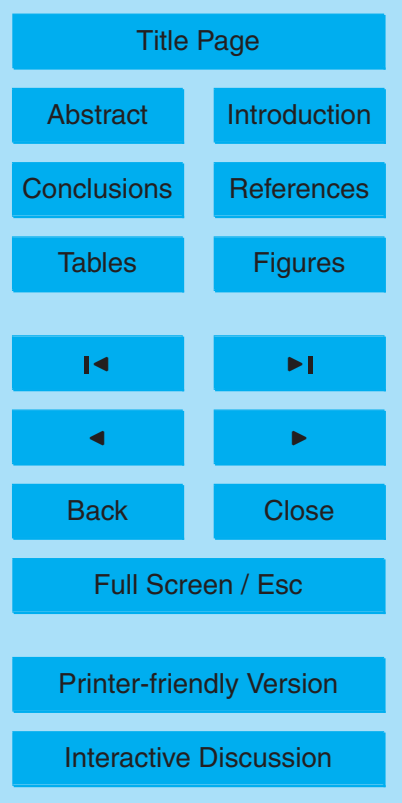


Lacis, A. A., Wuebbles, D. J., and Logen, J. A.: Radiative forcing of climate by changes in vertical distribution of ozone, J. Geophys. Res., 95, 9971-9981, 1990. 16134, 16141, 16142

Lamarque, J. F., Hess, P., Emmons, L., Buja, L., Washington, W., and Granier, C.: Tropospheric ozone evolution between 1890 and 1990, J. Geophys. Res., 110, 1-15, 2005. 16140

5 Land, C., Ponater, M., Sausen, R., and Roeckner, E.: The ECHAM4.L39/DLR atmosphere GCM - technical description and model climatology, DLR Forschungsbericht 1999-31, Köln, ISSN 1434-8454, 1999. 16134

Lin, X., Trainer, M., and Liu, S. C.: On the nonlinearity of the tropospheric ozone production, J. Geophys. Res., 93, 15879-15888, 1988. 16139

10 Matthes, S.: Globale Auswirkung des Straßenverkehrs auf die chemische Zusammensetzung der Atmosphäre, Ph.D. thesis, IIDO-Berichtsjahr=2003, 2003. 16136

Matthes, S., Grewe, V., Sausen, R., and Roelofs, G.-J.: Global impact of road traffic emissions on tropospheric ozone, Atmos. Chem. Phys., 7, 1707-1718, 2007, http://www.atmos-chem-phys.net/7/1707/2007/. 16133, 16144

Ramanathan, V. and Dickinson, R. E.: The role of stratospheric ozone in the zonal and seasonal radiative energy balance of the Earth-troposphere system, J. Atmos. Sci., 36, 1084-1104, 1979. 16132

Ramanathan, V., Callis, L. B., and Boughner, R. E.: Sensitivity of Surface Temperature and Atmospheric Temperature to Perturbations in the Stratospheric Concentration of Ozone and

$20 \quad$ Nitrogen Dioxide, J. Atmos. Sci., 33, 1092-1112, 1976. 16132, 16141

Roeckner, E., Arpe, K., Bengtsson, L., Christoph, M., Claussen, M., Dümenil, L., Esch, M., Giorgetta, M., Schlese, U., and Schulzweida, U.: The atmospheric general circulation model ECHAM-4: Model description and simulation of present-day climate, Report No. 218, MaxPlanck-Institut für Meteorologie, Hamburg, 1996. 16134

Sausen, R., Isaksen, I., Hauglustaine, D., Grewe, V., Lee, D. S., Myhre, G., Köhler, M. O., Pitari, G., Schumann, U., Stordal, F., and Zerefos, C.: Aviation radiative forcing in 2000: An update on IPCC (1999), Meteorol. Z., 14, 555-561, doi:10.1127/0941-2948/2005/0049, 2005. 16144

Schnadt, C., Dameris, M., Ponater, M., Hein, R., Grewe, V., and Steil, B.: Interaction of atmospheric chemistry and climate and its impact on stratospheric ozone, Clim. Dynam., 18, 501-517, 2002. 16135

Shine, K. P., Bourqui, M. S., Forster, P. M. d. F., Hare, S. H., Langematz, U., Braesicke, P., Grewe, V., Ponater, M., Schnadt, C., Smith, C. A., Haigh, J. D., Austin, J. Butchart, N.,

\section{Attribution of ozone radiative forcing trend to individual $\mathrm{NO}_{x}$ sources}

K. Dahlmann et al.

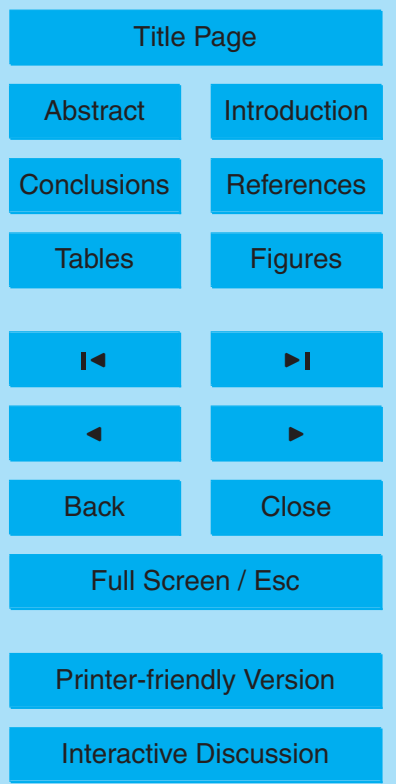


Shindell, D. T., Randel, W. J., Nagashima, T., Portmann, R. W., Solomon, S., Seidel, D. J., Lanzante, J., Klein, S., Ramaswamy, V., and Schwarzkopf, M. D.: A comparison of modelpredicted trends in stratospheric temperatures, Q. J. Roy. Meteorol. Soc., 129, 1565-1588, 2003. 16135

5 Steil, B., Dameris, M., Brühl, C., Crutzen, P. J., Grewe, V., Ponater, M., and Sausen, R.: Development of a chemistry module for GCMs: first results of a multiannual integration, Ann. Geophys., 16, 205-228, 1998, http://www.ann-geophys.net/16/205/1998/. 16134

Steinkamp, J., Ganzeveld, L. N., Wilcke, W., and Lawrence, M. G.: Influence of modelled soil biogenic $\mathrm{NO}$ emissions on related trace gases and the atmospheric oxidizing efficiency, Atmos. Chem. Phys., 9, 2663-2677, 2009, http://www.atmos-chem-phys.net/9/2663/2009/. 16140

Stuber, N., Sausen, R., and Ponater, M.: Stratospheric adjusted radiative forcing calculations in a comprehensive climate model, Theor. Appl. Climatol., 68, 125-135, 2001. 16133, 16137

Stuber, N., Ponater, M., and Sausen, R.: Why radiative forcing might fail as a predictor of climate change, Clim. Dynam., 24, 497-510, 2005. 16137

Toumi, R., Haigh, J. D., and Law, K.: A tropospheric ozone-lightning climate feedback, Geophys. Res. Lett., 23, 1037-1040, 1996. 16144

Unger, N., Shindell, D., Koch, D. N., and Streets, D. G.: Air pollution radiative forcing from specific emissions sectors at 2030, J. Geophys. Res., 113(2), D02306, doi:10.1029/2007JD008683, 2008. 16144

Uno, I., He, Y., Ohara, T., Yamaji, K., Kurokawa, J.-I., Katayama, M., Wang, Z., Noguchi, K., Hayashida, S., Richter, A., and Burrows, J. P.: Systematic analysis of interannual and seasonal variations of model-simulated tropospheric $\mathrm{NO}_{2}$ in Asia and comparison with GOMEsatellite data, Atmos. Chem. Phys., 7, 1671-1681, 2007, http://www.atmos-chem-phys.net/7/1671/2007/. 16140

Wang, W. C., Pinto, J. P., and Yung, Y. L.: Climate effects due to halogenated compounds in the Earth's atmosphere, J. Atmos. Sci., 37, 333-338, 1980. 16132

WMO (World Meteorological Organization): Scientific assessment of ozone depletion: 2002,

\section{Attribution of ozone radiative forcing trend to individual $\mathrm{NO}_{x}$ sources}

K. Dahlmann et al.

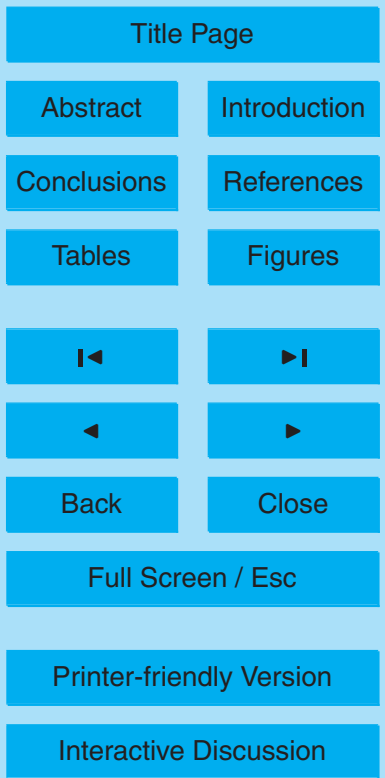




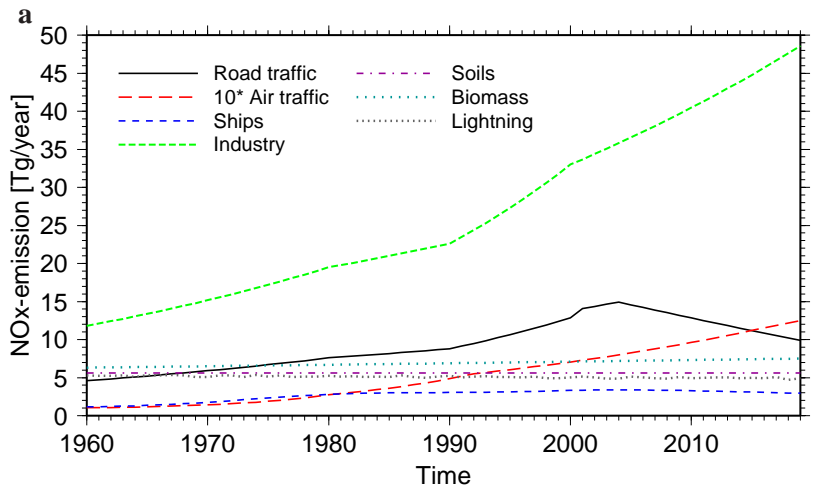

\section{ACPD}

9, 16131-16162, 2009

\section{Attribution of ozone radiative forcing trend to individual $\mathrm{NO}_{\mathrm{x}}$ sources}

K. Dahlmann et al.

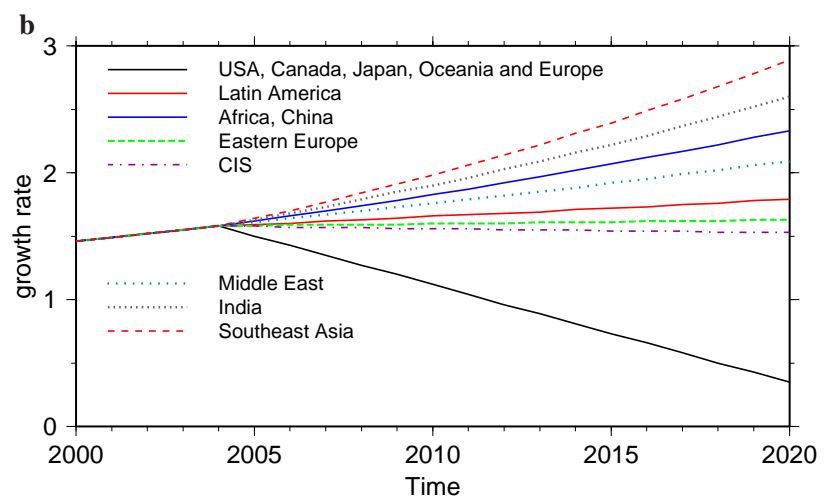

Title Page

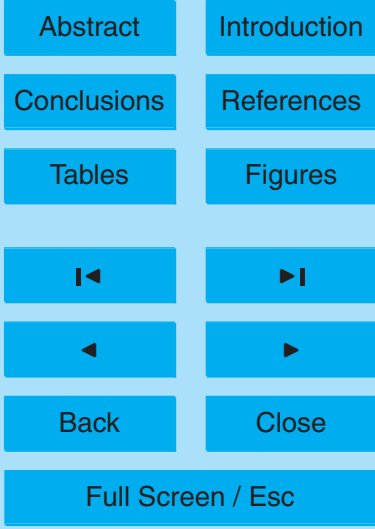

Fig. 1. Trends in $\mathrm{NO}_{\mathrm{x}}$-emission (a) of road traffic (solid black), air traffic (dashed red, scaled by a factor 10), ships (dashed blue), industry (dashed green), soils (dashed-dotted purple), biomass burning (dotted light blue) and lightning (dotted grey) in $\mathrm{Tg}(\mathrm{N}) / \mathrm{a}$. And (b) road traffic growth rates of between 2000 and 2020 in relation to 1990 emissions for industrial regions (solid black), Latin America (solid red), Africa and China (solid blue), Eastern Europe (dashed green), CIS (Commonwealth of Independent States, dashed-dotted purple), Middle Eastern (dotted light blue), India (dotted grey) and Southeast Asia (dashed red). 


\section{ACPD}

9, 16131-16162, 2009

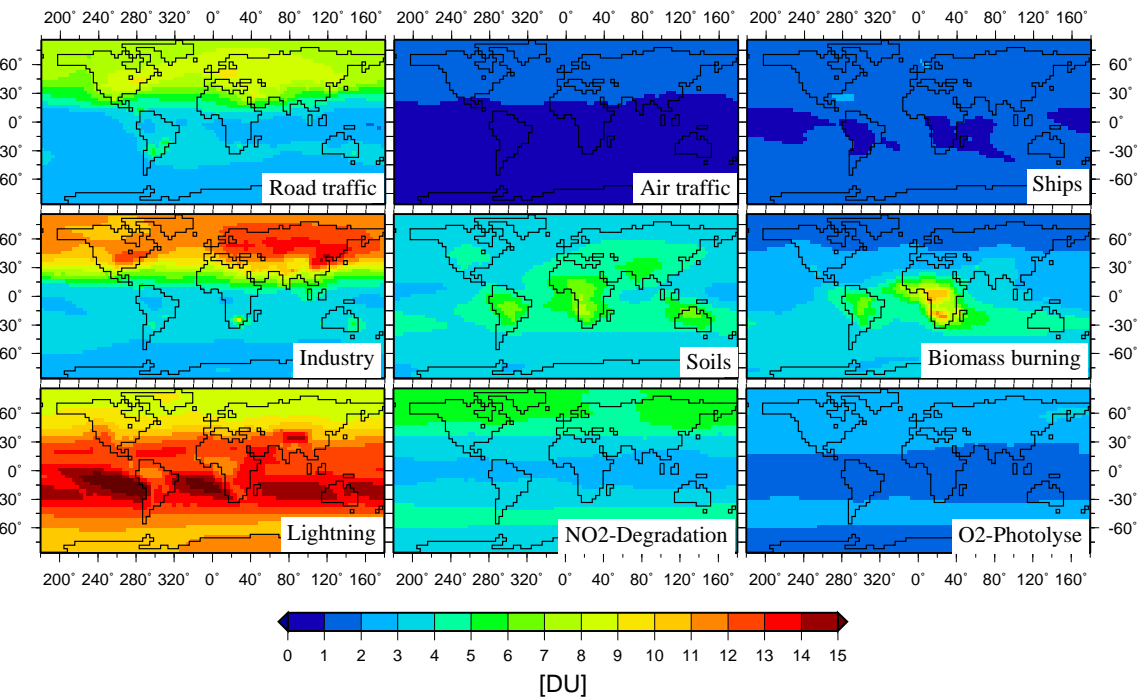

\section{Attribution of ozone radiative forcing trend to individual $\mathrm{NO}_{x}$ sources}

K. Dahlmann et al.

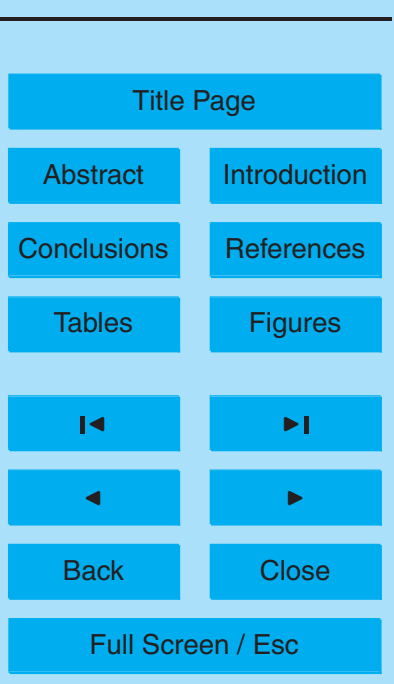

Fig. 2. Decadal mean ozone column of the 1990s in DU according to their sources: road traffic, air traffic, ships, industry, soils, biomass burning, lightning, $\mathrm{NO}_{2}$-Degradation and $\mathrm{O}_{2}$-photolysis. For a better visibility $\mathrm{NO}_{2}$-Degradation is multiplied with a factor of 0.1 and $\mathrm{O}_{2}$-photolysis with a factor of 0.01 .

Printer-friendly Version

Interactive Discussion 


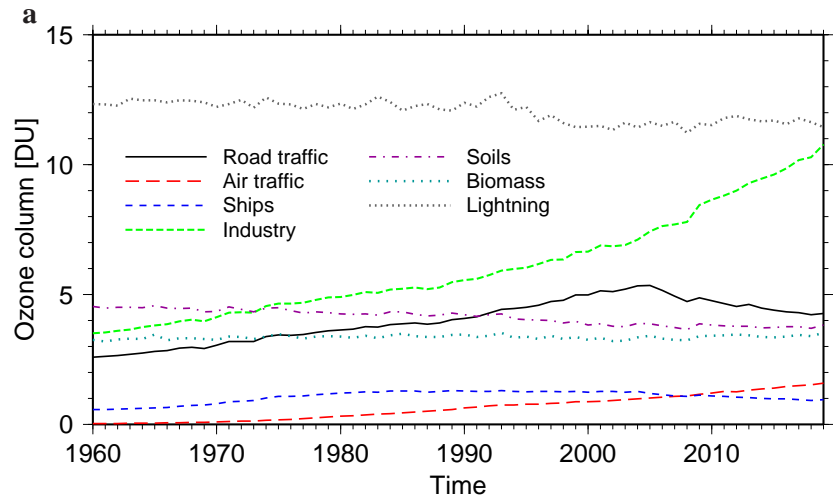

\section{Attribution of ozone radiative forcing trend to individual $\mathrm{NO}_{\mathrm{x}}$ sources}

K. Dahlmann et al.

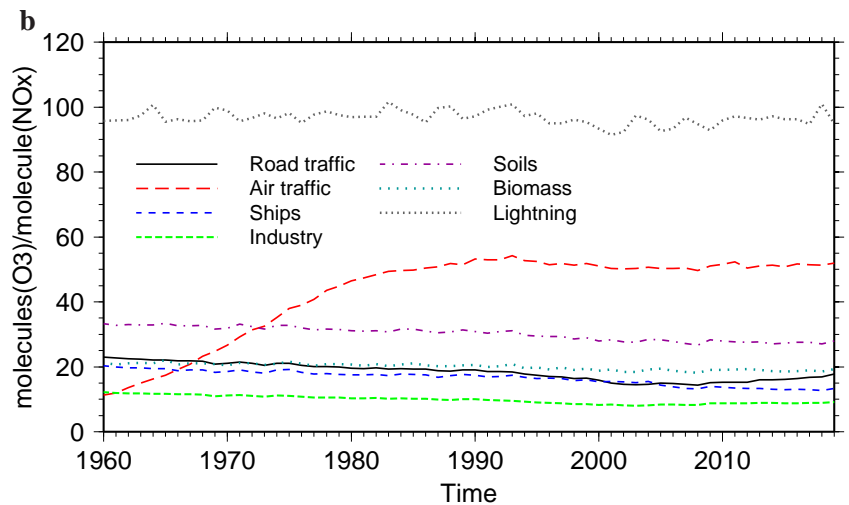

Title Page

Abstract Introduction

Conclusions

References

Tables

Figures

14

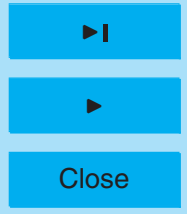

Back

Close

Full Screen / Esc

cency (b) in molecules $\left(\mathrm{O}_{3}\right)$ /molecule $\left(\mathrm{NO}_{x}\right)$ for road traffic (black solid), air traffic (dashed red), ships (dashed blue), industry (dashed green), soils (dashed-dotted purple), biomass burning (dotted light blue) and lightning (dotted grey).

Printer-friendly Version

Interactive Discussion 


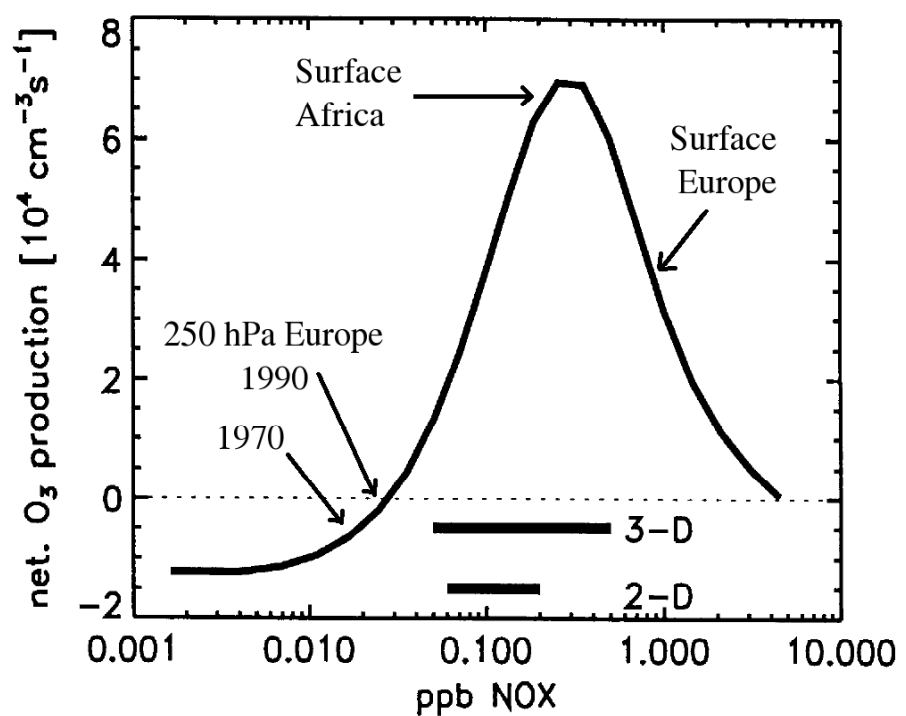

Fig. 4. Net $\mathrm{O}_{3}$-production rate in relation to background $\mathrm{NO}_{x}$ with some examples of typical $\mathrm{NO}_{x}$ values (adapted from Grooß et al., 1998).
9, 16131-16162, 2009

\section{Attribution of ozone radiative forcing trend to individual $\mathrm{NO}_{x}$ sources}

K. Dahlmann et al.

Title Page

Abstract

Introduction

Conclusions

References

Tables

Figures

14

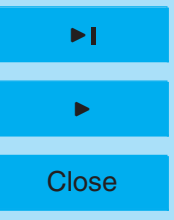

Back

Full Screen / Esc

Printer-friendly Version

Interactive Discussion 


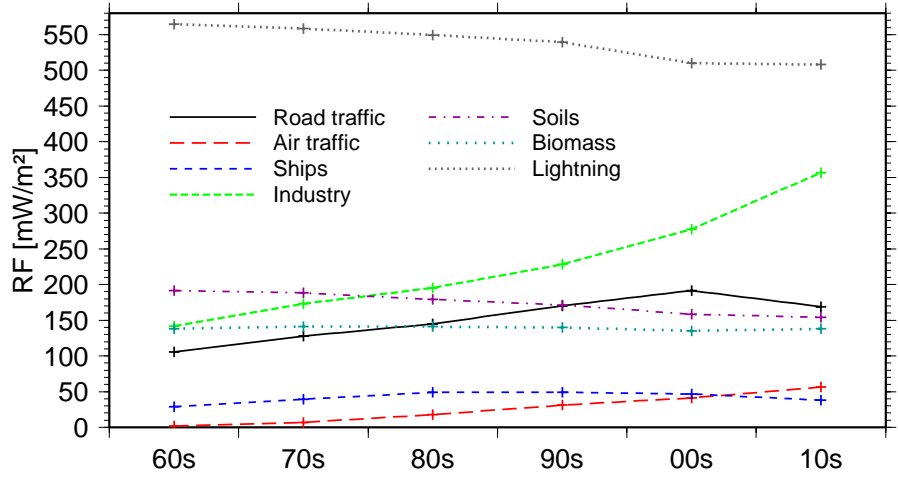

Fig. 5. Trends in RF of road traffic (black solid), air traffic (dashed red), ships (dashed blue), industry (dashed green), soils (dashed-dotted purple), biomass burning (dotted light blue) and lightning (dotted grey) in $\mathrm{mW} / \mathrm{m}^{2}$.

\section{Attribution of ozone radiative forcing trend to individual $\mathrm{NO}_{x}$ sources}

K. Dahlmann et al.

Title Page

Abstract

Introduction

Conclusions

References

Tables

Figures

14



Back

Full Screen / Esc

Printer-friendly Version

Interactive Discussion 


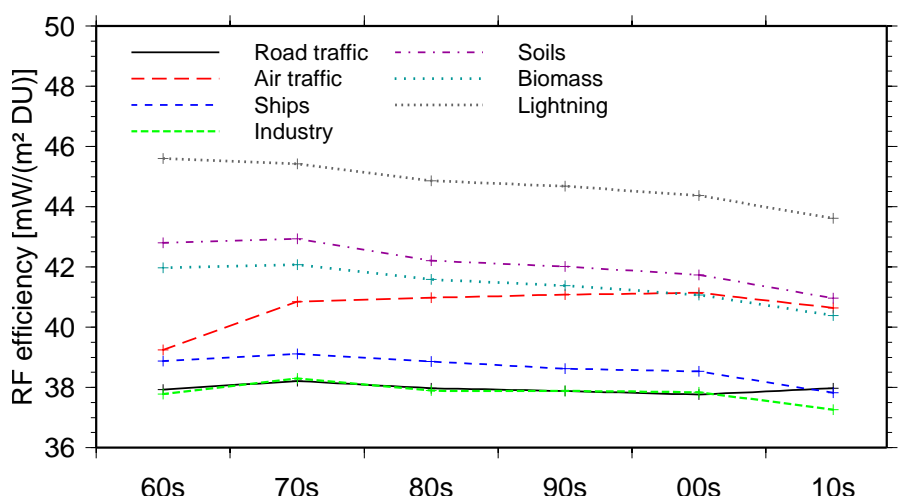

Fig. 6. Trends in RF efficiency of road traffic (black solid), air traffic (dashed red), ships (dashed blue), industry (dashed green), soils (dashed-dotted purple), biomass burning (dotted light blue) and lightning (dotted grey) in $\mathrm{mW} /\left(\mathrm{m}^{2} \mathrm{DU}\right)$.

\section{Attribution of ozone radiative forcing trend to individual $\mathrm{NO}_{x}$ sources}

K. Dahlmann et al.

Title Page

Abstract Introduction

Conclusions References

14

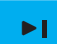

4

Back

Close

Full Screen / Esc

Printer-friendly Version

Interactive Discussion 


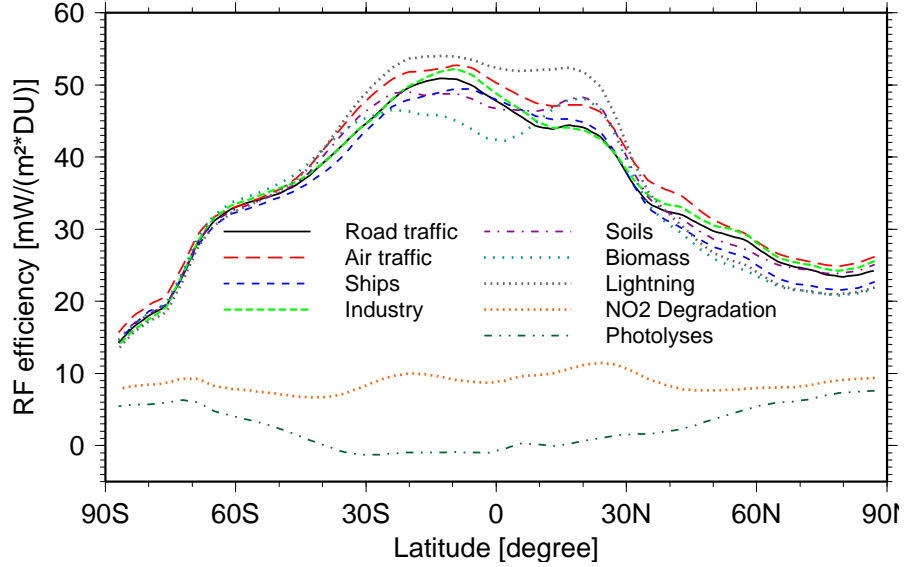

Fig. 7. Zonal mean of RF efficiency of road traffic (solid black), air traffic (dashed red), ships (dashed blue), industry (dashed green), soils (dashed-dotted purple), biomass burning (dotted light blue), lightning (dotted grey), stratospheric production (dotted orange) and $\mathrm{O}_{2}$-photolysis (dashed-dotted dark green) for 2010-2019 in $\mathrm{mW} /\left(\mathrm{m}^{2} \mathrm{DU}\right)$.

\section{Attribution of ozone radiative forcing trend to individual $\mathrm{NO}_{x}$ sources}

K. Dahlmann et al.

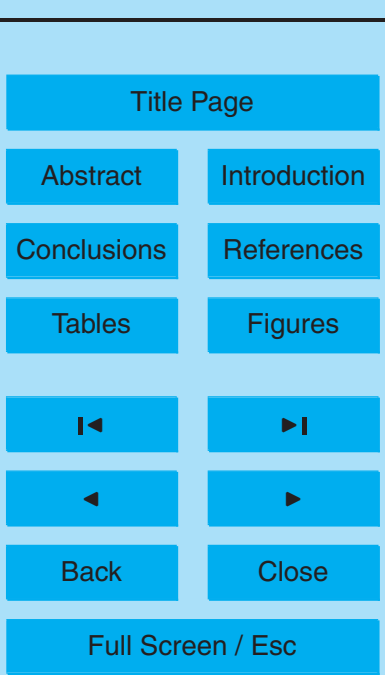

Printer-friendly Version

Interactive Discussion 


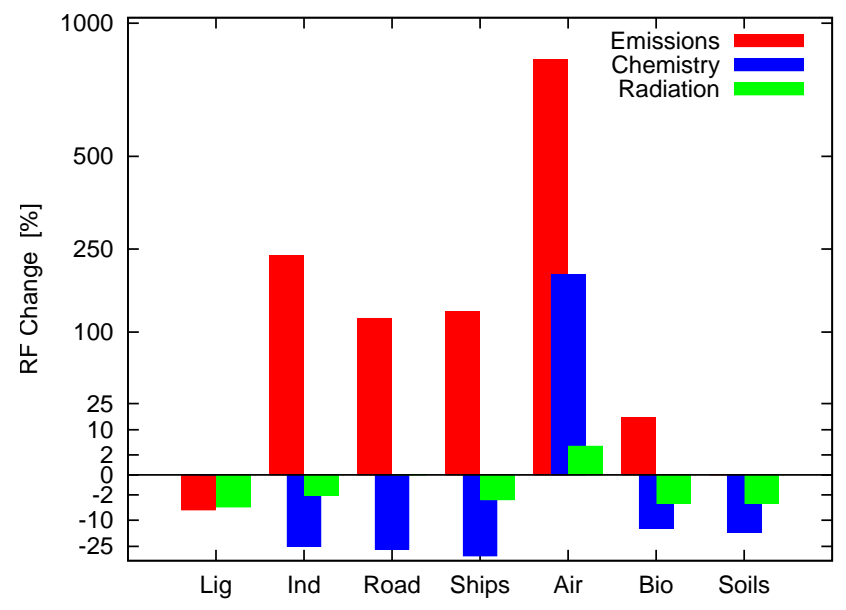

Fig. 8. Trends of $\mathrm{NO}_{\mathrm{x}}$ emissions (red), ozone production efficiency (blue) and RF efficiency (green) from 1960 to 2019 for lightning, industry, road traffic, ships, air traffic, biomass burning and soil emissions. The chemistry effect of lightning and the radiation effect of road traffic are too small to be seen in this kind of picture.

\section{Attribution of ozone radiative forcing trend to individual $\mathrm{NO}_{x}$ sources}

K. Dahlmann et al.

Title Page

Abstract

Conclusions

\section{Tables}

14

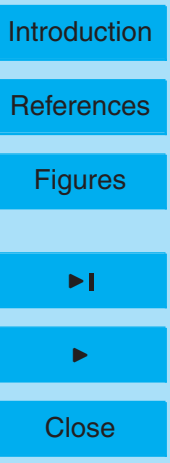

Back

Full Screen / Esc

Printer-friendly Version

Interactive Discussion 


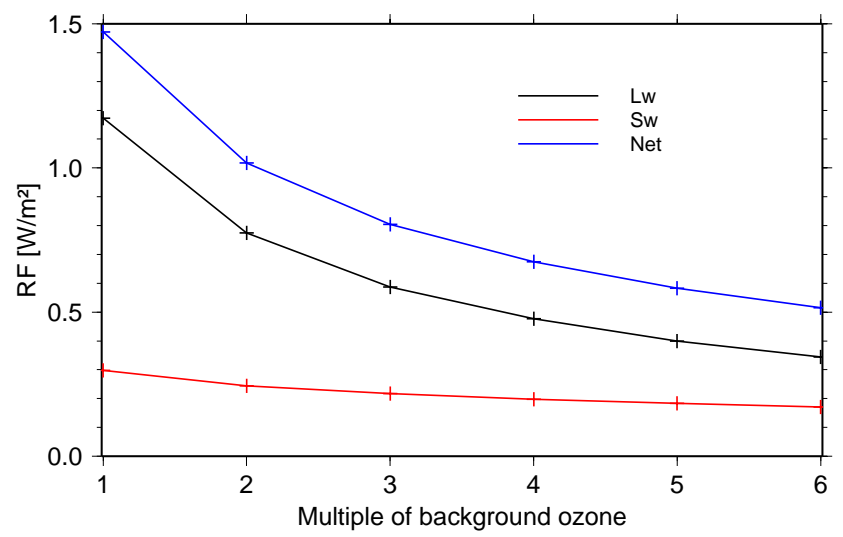

Fig. 9. Dependancy of RF of tropospheric sources in $\mathrm{W} / \mathrm{m}^{2}$ on background ozone in units of absolute ozone fields of the 1990s. Lw RF (solid black), sw RF (solid red) and net RF (solid blue) are presented separately.
ACPD

9, 16131-16162, 2009

\section{Attribution of ozone radiative forcing trend to individual $\mathrm{NO}_{x}$ sources}

K. Dahlmann et al.

Title Page
Abstract

Conclusions

Tables

14

4

Back
Introduction

References

Figures

$\rightarrow$



Close
Full Screen / Esc

Printer-friendly Version

Interactive Discussion 


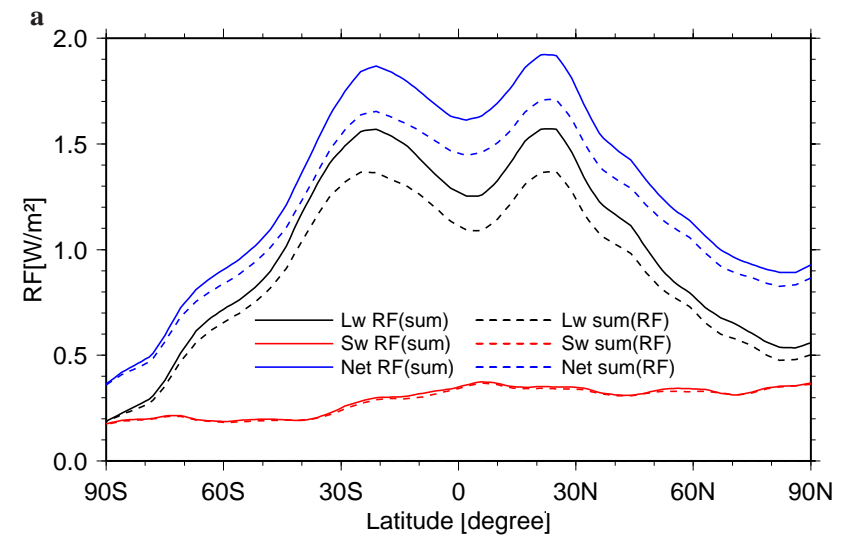

\section{ACPD}

9, 16131-16162, 2009

\section{Attribution of ozone radiative forcing trend to individual $\mathrm{NO}_{x}$ sources}

K. Dahlmann et al.

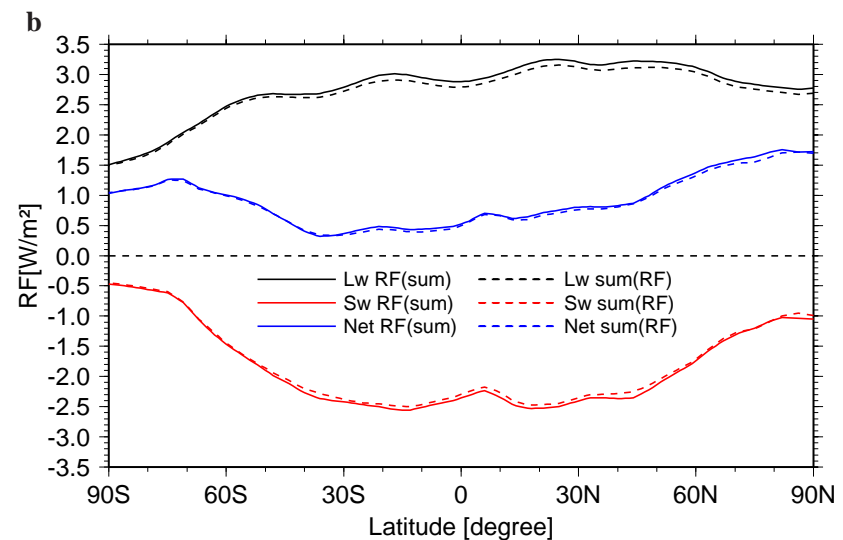

Title Page

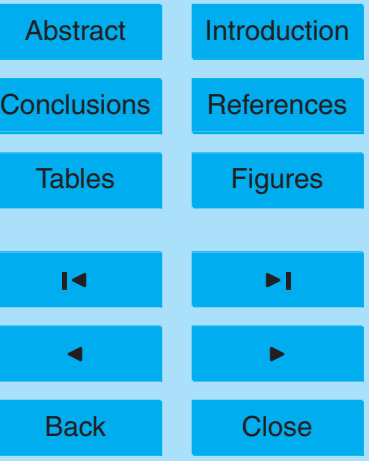

Full Screen / Esc

Fig. 10. Nonlinearity of RF of tropospheric sources (a) and stratospheric sources (b). Lw RF (black), sw RF (red) and net RF (blue) for the RF calculation of the sum of disturbance (solid) and the sum of separately calculated RF (dashed).

Printer-friendly Version

Interactive Discussion 